
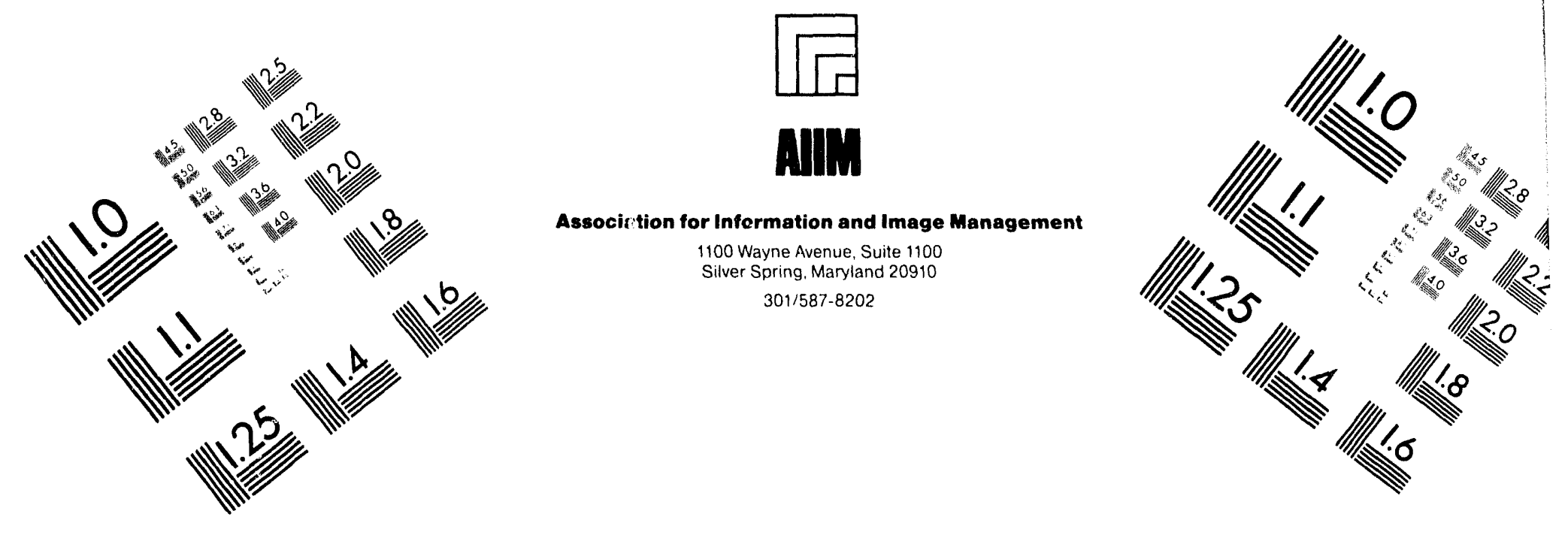

\title{
Centimeter
}

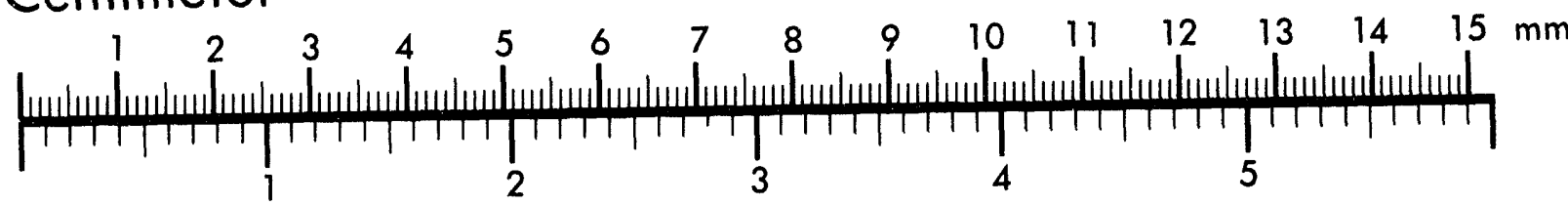
Inches
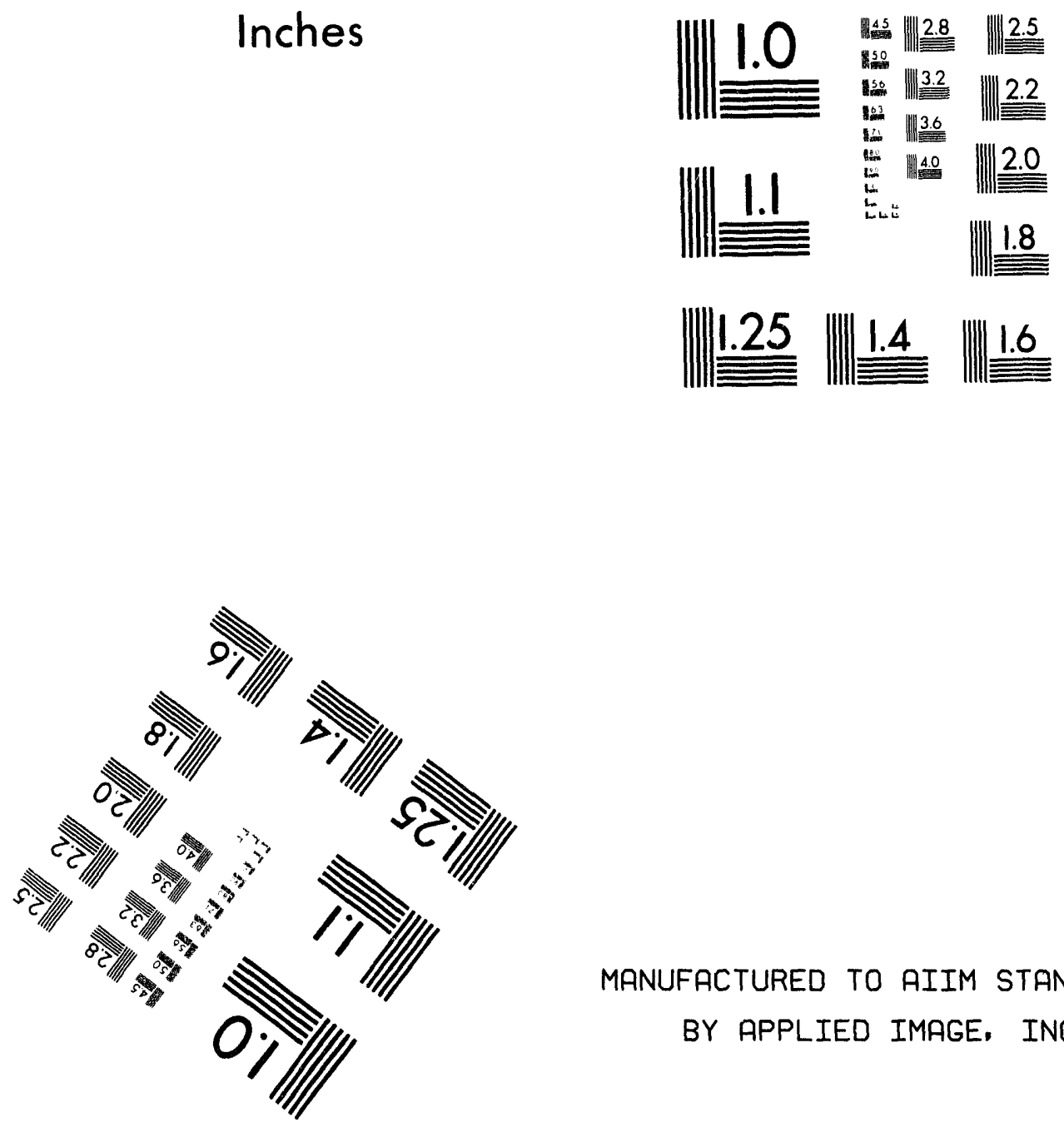

MANUFACTURED TO AIIM STANDARDS BY APPLIED IMAGE, INC.

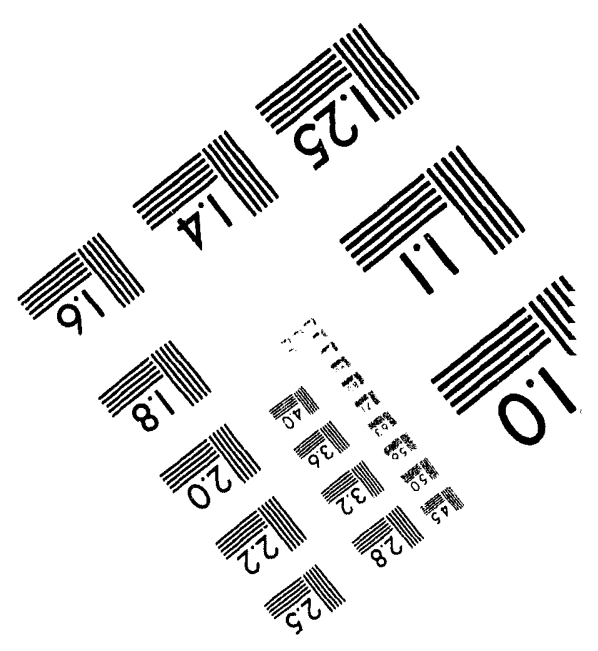






\section{CAM AND STACK AIR SAMPLER DESIGN GUIDE (U)}

by

Phillips, T. D.

Westinghouse Savannah River Company

Savannah River Site

Alken, South Carolina 29808

DOE Contract No. DE-AC09-89SR18035

This paper was prepared in connection with work done under the above contract number with the U.S.

Department of Energy. By acceptance of this paper, the publisher and/or recipient acknowledges the U.S.

Government's right to retain a nonexclusive, royalty-free license in and to any copyright covering this paper, along with the right to reproduce and to authorize others to reproduce all or part of the copyrighted paper.

$$
4+4 a^{4}
$$




\section{DISCLAIMER}

This report was prepared as an account of work sponsored by an ageacy of the United States Government. Neither the United States Government nor any agency thereof, nor any of their employees. makes any warranty, express or implied. or assumes any legal liability or responsibility for the accuracy. completeness, or usefulness of any information. apparatus, product, or process disclosed, or represents that its use would not infriage privately owned rights. Refereace hereia to any specific commercial product, process, or service by trade aame, trademark. manufacturer, or otherwise does not necessarily constitute or imply its endorsement, recommendation, or favoring by the United States Government or any agency thereof. The views and opiaions of authors expressed berein do not aecessarily state or reflect those of the Uaited States Government or any ageacy ithereof.

This report has been reproduced directly from the best available copy.

Available to DOE and DOE coatractors from the Office of Scieatific and Technical Information. P. O. Box 62. Oak Ridge. TN 37831; prices available from (615) $576-8401$.

Available to the public from the National Technical Information Service. U. S. Deparmeat of Commerce, 5285 Port Royal Rd., Sprinefield. VA 22161 
CAM AND STACK AIR SAMPLER DESIGN GUIDE (U)

$5 / 19 / 94$

DISTRIBUTION:

$\begin{array}{ll}\text { G. T. Wright } & 703 \mathrm{H} \\ \text { J. W. French } & 703 \mathrm{H} \\ \text { E. R. Losure } & 707 \mathrm{H} \\ \text { G. Davis } & 241-100 \mathrm{~F} \\ \text { T. M. Monahon } & 703 \mathrm{H} \\ \text { V. G. Dicker } & 703 \mathrm{H} \\ \text { H. Handfinger } & 704-56 \mathrm{H} \\ \text { W. C. Clark } & 241-119 \mathrm{H} \\ \text { W. F. Bates } & 703 \mathrm{H} \\ \text { M. A. Ceravolo } & 707 \mathrm{H} \\ \text { E. M. Tshishiku } & 703 \mathrm{H} \\ \text { G. B. Glendenen } & 703-6 \mathrm{C} \\ \text { B. R. Hess } & 241-100 \mathrm{~F} \\ \text { A. W. Wiggins } & 241-84 \mathrm{H} \\ \text { A. G. Weist } & 707-1 \mathrm{H} \\ \text { D. L. Daniels } & 707-41 \mathrm{~B} \\ \text { D. Zupon } & 966 \mathrm{~W}-410 \\ \text { J. B. Guilherme } & 703 \mathrm{H} \\ \text { C. G. Kelly } & 707 \mathrm{H} \\ \text { K. A. Hauer } & 241-100 \mathrm{~F} \\ \text { C. A. Polson } & 707 \mathrm{H} \\ \text { M. P. Reimnitz } & 703-6 \mathrm{H} \\ \text { B. L. Lewis } & 703-8 \mathrm{C} \\ \text { T. L. Orner } & 241-152 \mathrm{H} \\ \text { E. A. Cabacungan } & 703 \mathrm{H}\end{array}$

S. G. Brown $\quad 707 \mathrm{H}$

D. E. McLane 704-8H

K. Collins 241-197H

K. F. Lesko $707 \mathrm{H}$

E. Saldivar $\quad 703 \mathrm{H}$

M. S. Peters 707-2H

G. D. Thaxton 241-119H

R. L. Salizzoni $707 \mathrm{H}$

H. A. Abodishish $707 \mathrm{H}$

M. E. Jamison 707-1H

D. J. Martin $707 \mathrm{H}$

R. P. Blundy $992-4 \mathrm{~W}$

L. T. Suttinger $\quad 966 \mathrm{~W} / 410$

A. O. Delley 730B

B. Blunt 742A

E. W. Zimmerman $966 \mathrm{~W} / 410$

D. Speed 675-1T

V. F. Bohman $\quad 707-1 \mathrm{H}$

G. R. Huff 704-56H

R. W. Smith 996W-B20

R. R. Hopkins 707-41B

Deepak Bhasin 996W-B15

W. Perry 730B

Tech info mng(4) 703-43A

HLWE file room $703 \mathrm{H}$ 
WESTINGHOSE SAVANNAH RIVER CO.

HIGH LEVEL WASTE ENGINEERING

W SR C - T R-94-0236

REVISION

KEYWORDS: Air monitor Air sampler CAM

RETENTION: Permanent

CLASSIFICATION

Q.G.Acoege s/10/94

Authorized Derivitive

Classifier SR-1C-S, her

\section{CAM AND STACK_AIR SAMPLER DESIGN GUIDE (U)}

b y

Terrance $D$. Phillips

issued $5 / 13 / 94$

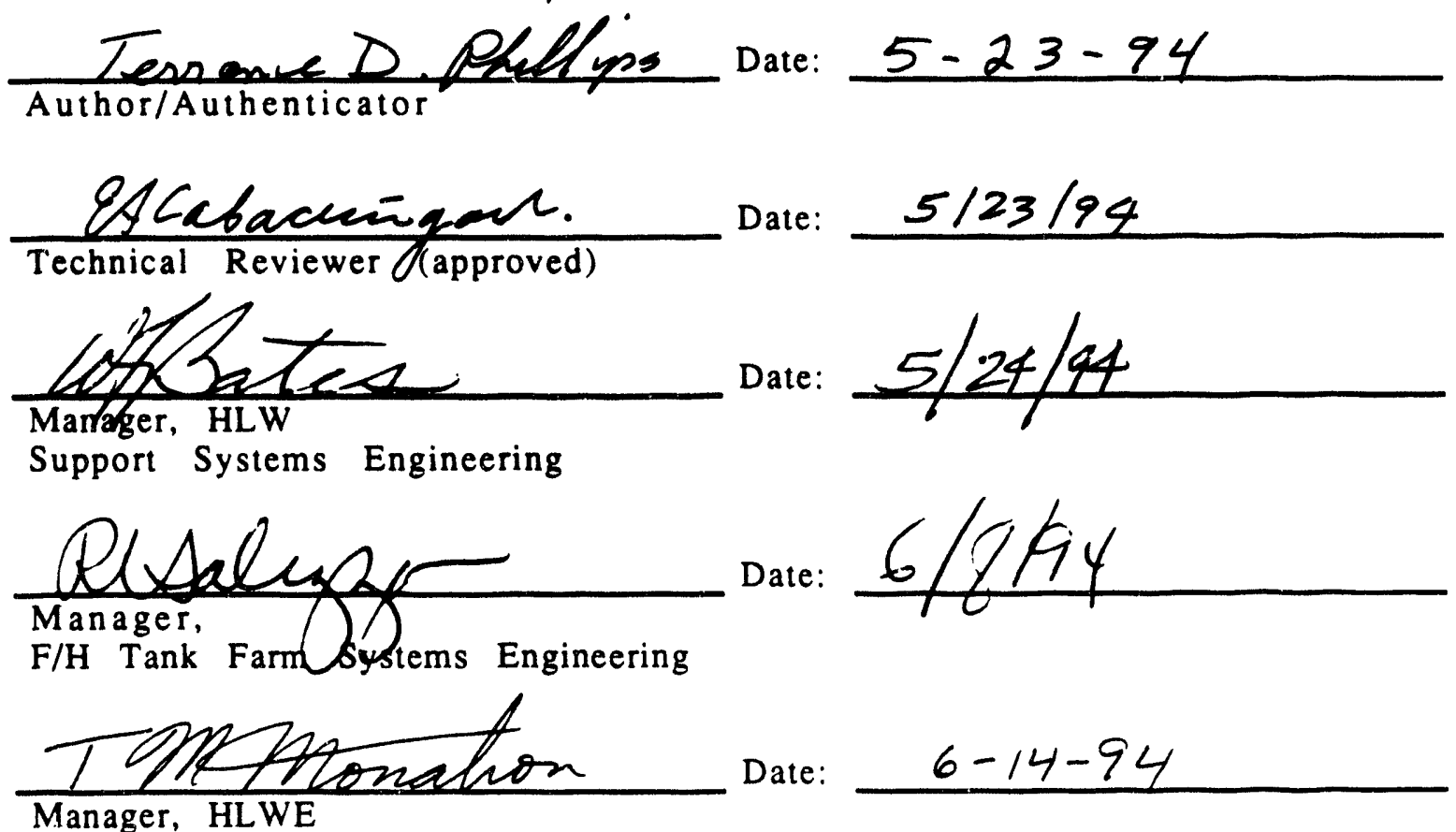

Manager, HLWE 


\section{INTRODUCTION}

Ventilation stacks in the ' $H$ ' and ' $F$ ' area tank farms are equipped with air samplers or Continuous Air Monitors (CAMs) which are used to detect and document the quantity of radioactive particulate which could potentially be released to the atmosphere. In addition to their regulatory role, air samplers and CAMs are used to assure that the stack HEPAs (particle eliminators) are operating in a satisfactory manner. The samplers draw a nominal $3 \mathrm{cfm}$ air sample from the stack and cause the sample to pass through a 3 " diameter 1 micron porosity filter paper. Filter papers are collected and measured for radioactive buildup at least once per week. CAM type samplers include a radiation detector which initiates an alarm in the event high radiation is detected. In an effort to correct the numerous sample system deficiencies which have been identified, four CAM/air sampler projects have been initiated. The attached document provides design guidance for the standardized High Level Waste air sampling system.

\section{SUMMARY}

About 128 air samplers and CAMs presently in service to detect and document potential radioactive release from ' $H$ ' and ' $F$ ' area tank farm ventilation stacks are scheduled for replacement and/or upgrade by Projects S-5764, S-2081, S3603, and S-4516. The seven CAMs scheduled to be upgraded by Project S-4516 during 1995 are expected to provide valuable experience for the three remaining projects. The attached document provides design guidance for the standardized High Level Waste air sampling system.

\section{DISCUSSION}

Air sampler and CAM design is intended to be as simple as possible while adhering to the spirit and letter of applicable Federal regulations. Systems will use manual readout and manual adjustment to achieve isokinetic sampling. Equipment and instrumentation will be chosen for low maintenance, low sophistication, and long life expectancy. A new sample box has been developed which should eliminate many problems associated with the existing systems. The new box is scheduled to begin evaluation by the Texas A\&M Aerosol testing lab during June 1994.

The attachment is intended for use as a design guide for HLW CAM/sampler new designs. Deviation from these guides is permitted provided Design Authority personnel approve the alternative. It is the long term goal to present this TR to the site NESHAPS committee for incorporation into a site standard.

\section{ACTIONS}

none 
WSRC.TR-94.0236

Page 3 of 3

$5 / 13 / 94$

\section{REFERENCES}

1. Position paper, "CODES, ORDERS, AND STANDARDS, CONSTANT AIR MONITORS" (U) Document J-ESR-G-00001, July 301993

2. Memo, G. T. Wright to C. E. Anderson, "Request for corrective action plan for tank purge exhaust" Feb. 14, 1993, WER-HLE-930258

3. Procedure 314, Rev 6 Manual 5Q1.5, "241F and $241 \mathrm{H}$ Exhaust monitoring Systems"

4. Memo, A. B. Scott to S. D. Richardson, "Radiation Monitoring Equipment Update" Oct. 21 1993, HLW-HLE-93-1365

5. Action Plan, “Continuous Air Monitoring Systems Action Plan”, Jan. 61994, HLW-HLE-1492 


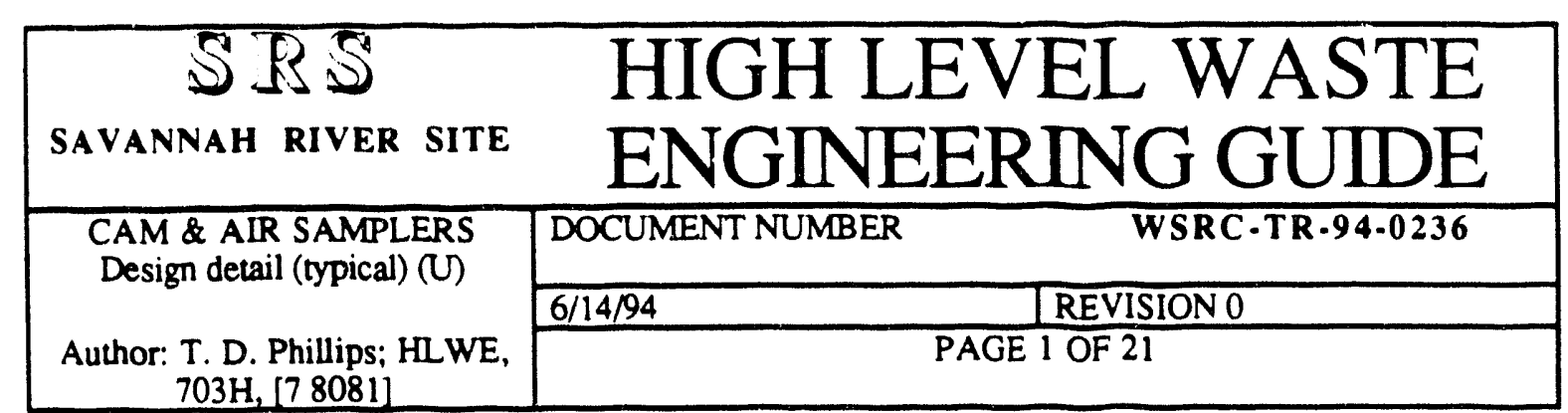

Scope

This guide is provides for the purpose of standardized engineering application of DOE directives at SRS, and does not create new DOE policy.

\section{Purpose}

Continuous Air Monitors [CAM] and unmonitored air samplers are used to collect and detect radioactive particles released through the waste storage ventilation stacks.

This document is intended to provide guidance for the detailed design of High Level Waste CAMs and non continuously monitored air samplers.

\section{Summary}

Detailed guidance is provided for the design of High Level Waste emission point stack air samplers and Continuous Air Monitors [CAMs]

\section{Current Status}

About 50 of the High Level Waste emission points are equipped with unmonitored air samplers. These devices are composed of a sample pump which draws a nominal $3 \mathrm{cfm}$ air sample from the exhaust duct to a sample box containing a $76 \mathrm{~mm}$ diameter filter paper through which the sample air is drawn.

The filter papers are collected and measured for radioactive buildup at least once per week; the analysis of radioactive particles coll $x$ cted becomes record data

The remaining $=78$ emission points are equipped with Constant Air Monitors (CAMs). Like the unmonitored samplers, CAMs are composed of a sample pump which draws a nominal $3 \mathrm{cfm}$ air sample from the exhaust duct to a sample box containing a $76 \mathrm{~mm}$ filter paper through which the sample air is drawn. The filter papers are collected and measured for radioactive buildup at least once per week; the analysis of radioactive particles collected becomes record data. In addition, the filter paper is continuously monitored for radioactivity via radiation detector. CAMs are equipped with control room activity and loss of flow alarms.

\section{Regulatory Requirements}

The design specified by this guide is in accordance with ANSI N13.1 and associated appendixes, DOE Regulatory Guide DOE/EH$0173 \mathrm{~T}$ which incorporates and expands on requirements embodied in DOE 5400.5 and DOE 5400.1., ANSI N42.17-1989; and 10 CFR 60

\section{High Level Waste Position}

'Best management practice' and ALARA design principles suggest that High Level Waste air emissions which originate from radioactive waste storage facilities require continuous proportional sampling [category II] or continuous monitoring [category I] contingent with their risk.

In addition to their regulatory role; Air somplers and CAMs are used to assure that the HEPA filters are operating in a satisfactory manner. Past HEPA failures have allowed contamination of the areas surrounding their associated stacks. Early HEPA failure detection minimizes contamination, clean up cost, and personnel exposure.

Based on historical data the actual emissions from High Level Waste emission stacks has contributed a calculated maximum dose to the public of less than $0.01 \mathrm{mrem} / \mathrm{yr}$.; however, the sampling equipment from which the historical data was accumulated does not meet current standards.

\section{Isokinetic Operation}

High Level Waste air samplers and CAMs should be designed to sample isokinetically by appropriate sizing of the sample nozzle diameter, and manual adjustment of the sample flow rate via the manual sample flow control valve (Figure 1).

Each unit should be equipped with an "operator guide" which indicates the correct sample rate 'rotameter' setting versus stack velocity 'gage' reading, and an "operator guide" which indicates the correct vacuum gage reading versus 'rotameter' reading. Systems should be designed to operate around a nominal $3 \mathrm{cfm}$ sample flow rate. 


\begin{tabular}{|c|c|c|}
\hline CAM \& AIR SAMPLERS & DOCUMENT NUMBER & WSRC.TR-94.0236 \\
\hline & $6 / 14 / 94$ & REVISION 0 \\
\hline $\begin{array}{l}\text { Author: T. D. Phillips; HLWE, } \\
703 \mathrm{H},[78081]\end{array}$ & \multicolumn{2}{|c|}{ PAGE 2 OF 21} \\
\hline
\end{tabular}

\begin{tabular}{|c|c|c|}
\hline Design Highlights & Function & page \\
\hline Low vacuum & \begin{tabular}{|l|} 
results from isokinetic system design \\
minimizes significance of inleakage
\end{tabular} & $11-13$ \\
\hline $\begin{array}{l}\text { Size sample nozzle for isokinetic at } 3 \mathrm{cfm} \text { sample } \\
\text { flow. }\end{array}$ & \begin{tabular}{|l|}
$\begin{array}{l}\text { reduce operator error by not requiring } \\
\text { different setting for each sampler }\end{array}$ \\
\end{tabular} & $4-6$ \\
\hline 0 to $30 "$ wc vacuum gage & \begin{tabular}{|l|}
$\begin{array}{l}\text { Maximize gage sensitivity to vacuum } \\
\text { change and ease of operator readout }\end{array}$ \\
\end{tabular} & 15 \\
\hline $\begin{array}{l}\text { Sample flow Rotameter should be chosen to } \\
\text { provide readout to within } 0.1 \mathrm{cfrn} \text {. }\end{array}$ & $\begin{array}{l}\text { Maximize gage sensitivity to flow change } \\
\text { and ease of operator readout. }\end{array}$ & 13 \\
\hline $\begin{array}{l}\text { Dynamic 'working vacuum' at } 3 \mathrm{cfm} \text { confirmation } \\
\text { useful during daily inspection of early detection of } \\
\text { gross flow and/or in-leakage problems. } \\
\text { Static vacuum in-leakage test favored for periodic } \\
\text { monthly or annual confirmation. }\end{array}$ & $\begin{array}{l}\text { Eliminates valve manipulation and } \\
\text { potential equipment damage due to high } \\
\text { vacuum. }\end{array}$ & 13 \\
\hline Heat CAM enclosure and CAM sample lines & \begin{tabular}{|l|}
$\begin{array}{l}\text { Eliminate condensation inside the sample } \\
\text { system }\end{array}$ \\
\end{tabular} & 7 \\
\hline Typical vacuum \& flow illustrated & & 11,16 \\
\hline Pump characteristic curve at $852 \mathrm{rpm}$ & & 18 \\
\hline Static leak test-dynamic leak test & & 13 \\
\hline Interlocks & no interlocks required by standard design & 15 \\
\hline Alarms & Describes control room alarms & 14 \\
\hline
\end{tabular}

\section{Standard Operation}

- Install new filter paper

- Close and seal drawer

- Record stack flow

- Adjust 'sample flow control valve' to set correct flow on 'rotameter' as determined from stack flow and the "operator guide".
- Confirm from "operator guide" that vacuum is in the expected range for the sample flow.

- Confirm that vacuum gage high and low alarm points are set to operate at \pm 0.5 " water column (wc). 


\begin{tabular}{|c|c|c|c|c|}
\hline & \multirow{3}{*}{. } & \multirow{3}{*}{$\begin{array}{c}\text { CAM \& AIR SAMPLERS } \\
\text { Design Detail typical (U) } \\
\text { Author: T. D. Phillips; HLWE, } \\
703 \mathrm{H},[78081]\end{array}$} & DOCUMENT NUMBER & WSRC.TR.94.0236 \\
\hline & & & $6 / 14 / 94$ & REVISION ( \\
\hline & & & \multicolumn{2}{|c|}{ PAGE 3 OF 21} \\
\hline
\end{tabular}

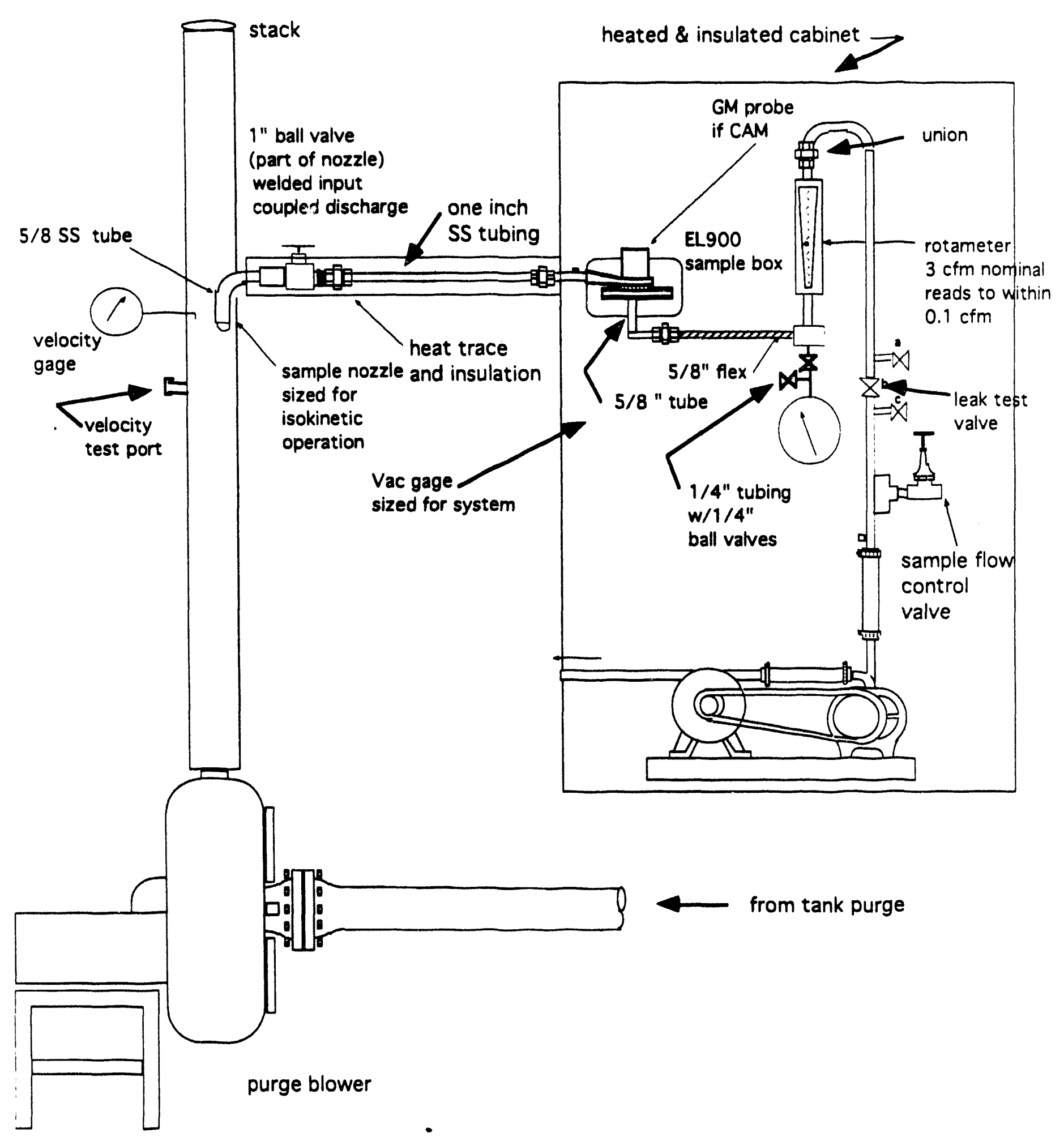

Eigure 1 


\begin{tabular}{|l|l|l|}
\hline $\begin{array}{c}\text { CAM \& AIR SAMPLERS } \\
\text { Design detail typical (U) }\end{array}$ & DOCUMENT NUMBER & \multicolumn{2}{|c|}{ WSRC·TR-0236 } \\
\cline { 2 - 3 } & $6 / 14 / 94$ & REVISION 0 \\
\cline { 2 - 3 } Author: T. D. Phillips; HLWE, & & PAGE 4 OF 21 \\
$703 \mathrm{H}, 778081]$ & &
\end{tabular}

Sample system

- Single sample nozzle

- One stack mounted velocity probe and readout gage

- One velocity test port.

- One inch SS tubing sample line insulated and heat traced to prevent condensation

- Leak test ball valve [1"] in sample input line [leak specification <.01 cfm @ 15" wc]

- 'Leak test valve' in vacuum supply line [suggest $5 / 8$ " ball valve with leak specification $<.01 \mathrm{cfm}$ @ 15" wc] Figure 1

- Enclosure insulated and/or heated to prevent condensation in sample box

- Raintight enclosure with single handle door to contain:

- sample box

- leak test discharge valve

- sample flow control valve

- sample pump

- sample rotameter

- Provide means to facilitate annual verification of rotameter accuracy*

- Photocapsulhelic vacuum gage 0 to 30 inch wc [desirable for gage range to be $0.5^{\prime \prime}$ greater than working vacuum]

- Vacuum tight SS tube fittings [leak specification <.03 cfm @ 30" wc]

* One possible method providing such a test arrangement is the addition of two additional valve on either side of the leak test valve (Figure 1). Recommend consultation with HP tech.

\section{Sample nozzle design}

Single probe designed per ANSI N13.1 \& DOE/EH--0173T Section 3.5.3.

Probe nozzles constructed of seamless stainless-steel ubing with a $30^{\circ}$ tapered outside edge to preserve a constant internal diameter. Changes in flow direction via bends having a curvature radius of at least 5 tube diameters.
Nozzle ID sized to provide isokinetic* sample velocity with a nominal sample rate of $3 \mathrm{cfm}$.

*Isokinetic - A condition which prevails when the velocity of air entering a sampling probe or the collector when held in the airstream is identical to the velocity of the airstream being sampled at that point. [ from ANSI N 13.1-1969 ]

Probe size calculations should be made assuming average expected stack airstream velocity. Tank farm data indicates that tank farm stack discharge rates remain constant to within \pm $10 \%$.

Sample nozzle [proposed] ID $=0.495$ " (the ID of 5/8 SS tubing). See Figure 3 for standard ANSI N13.1 design.

Isokinetic condition exists when the velocity of the sample air entering the nozzle is equal to the average velocity of the air traveling up the stack.

EXAMPLE

Tank purge

$342 \mathrm{cfm}$ stack flow up a 6" ID stack would result in a stack velocity of $1744 \mathrm{fpm}$

$(342 \mathrm{cfm} / 0.1962$ square feet $=1744 \mathrm{fpm})$

Nozzle area $=.0013364$ square feet

A flowrate of $2.33 \mathrm{cfm}$ is determined by multiplying the nozzle area and the stack velocity $.0013364 \times 1744=2.33 \mathrm{cfm}$

In order to maintain the sample flow rate between 2 and $4 \mathrm{cfm}$;

Nozzles should be constructed using 5/8" tubing for stack flow rates between 300 and $500 \mathrm{cfm}$

$3 / 4$ " tubing for stack flow rates of less than 300 $\mathrm{cfm}$, and

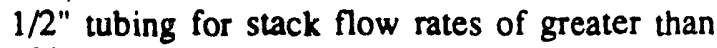
$500 \mathrm{cfm}$

Sample nozzle and location (Per DOE/EH-0173T, Section 3.5.2)

Install a single nozzle at a point of average stack velocity and uniform flow. Preferable nozzle location is in the vertical Section of the stack at least 8 stack diameters downstream and 2 stack diameters upstream from major flow disturbance. In no case should nozzle be located less than 2 stack diameters downstream and 0.5 stack diameters upstream from a flow disturbance 


\begin{tabular}{|c|c|c|}
\hline CAM \& AIR SAMPLERS & DOCUMENT NUMBER & WSRC.TR-94.0236 \\
\hline & $6 / 14 / 94$ & REVISION 0 \\
\hline $\begin{array}{c}\text { Author: T. D. Phillips; HLWE, } \\
703 \mathrm{H},[78081]\end{array}$ & \multicolumn{2}{|c|}{ PAGE 5 OF 21} \\
\hline
\end{tabular}

Figure 2 illustrates sample flow rates needed to establish isokinetic sampling for various nozzles versus stack flow rates

"iso sample nozzle study"

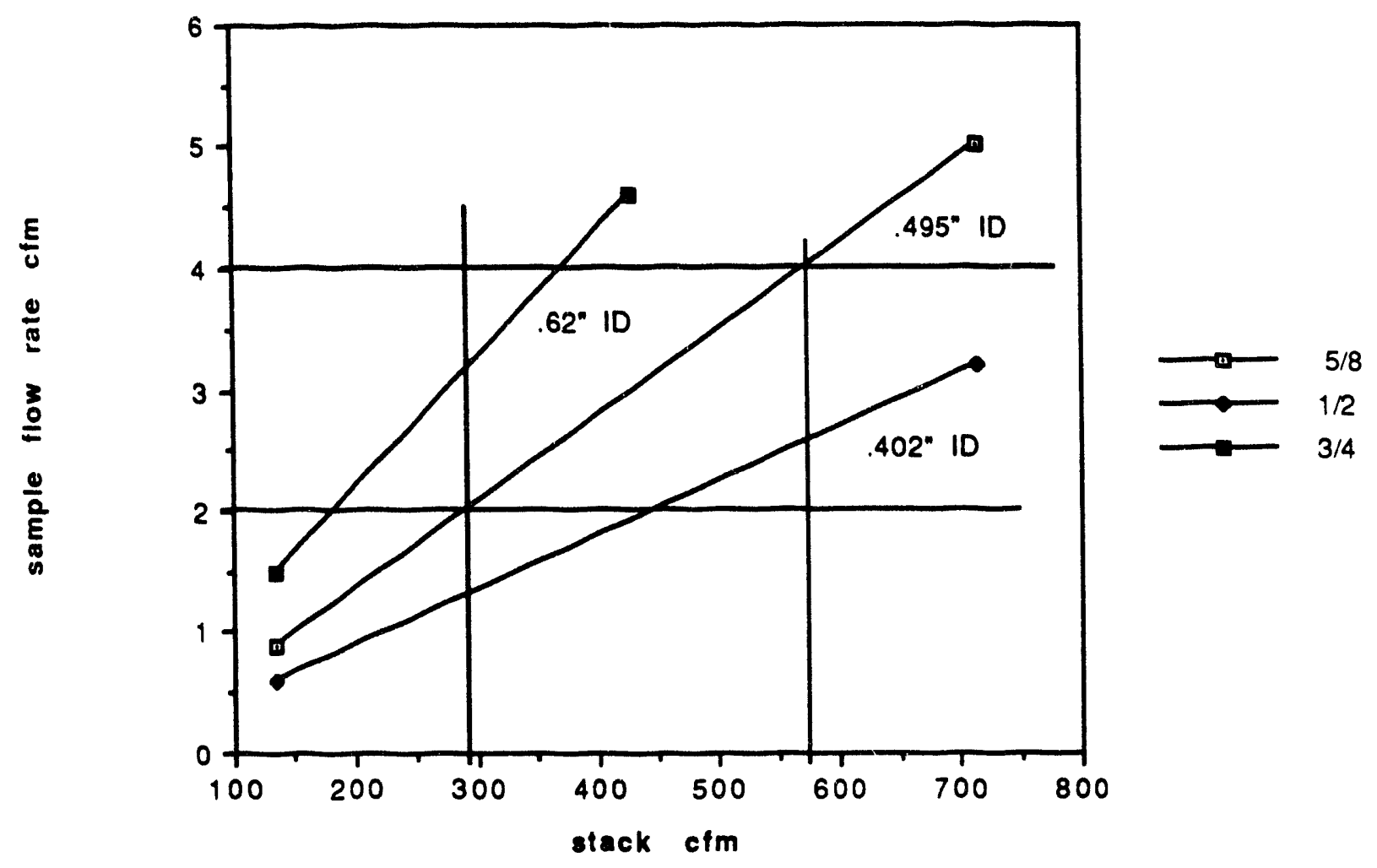

Data for 6 inch diameter stacks such as those installed on the type 3A purge systems

\section{Figure 2}




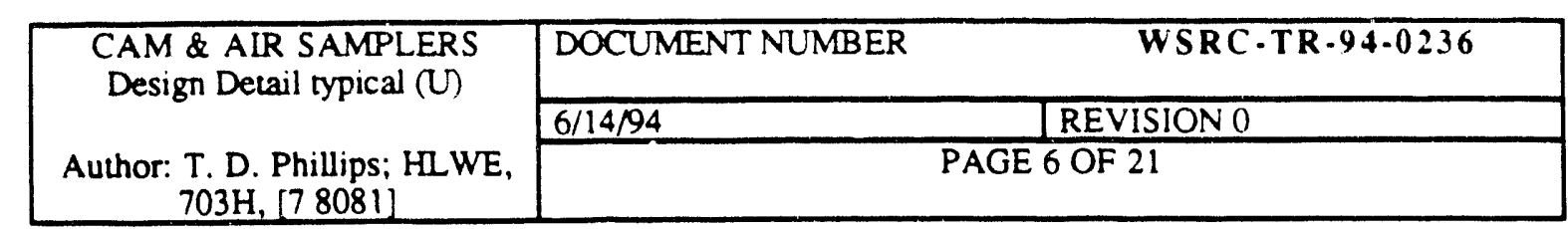

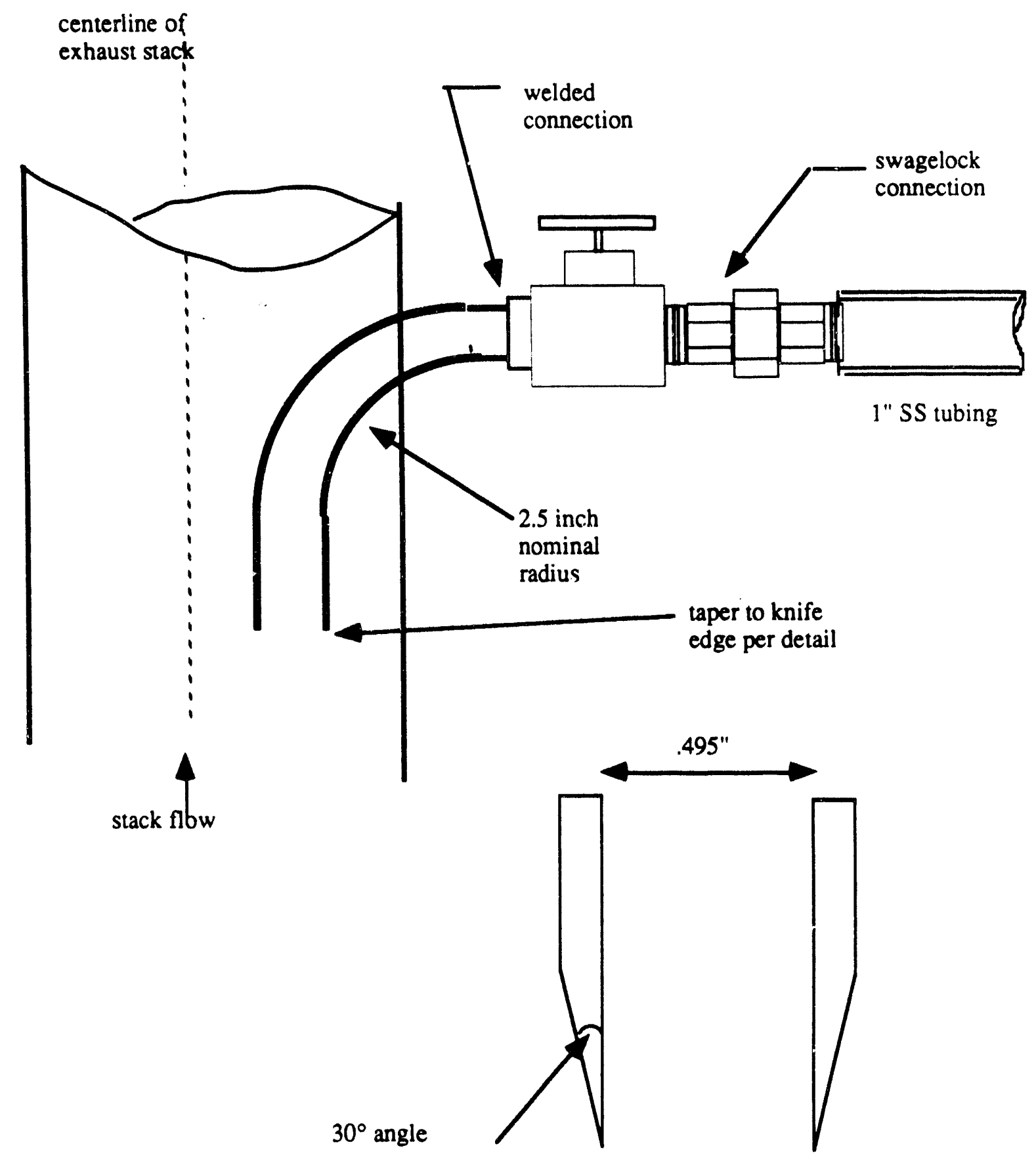

Knife edge detail for $5 / 8$ " tubing

- Eigure 3 


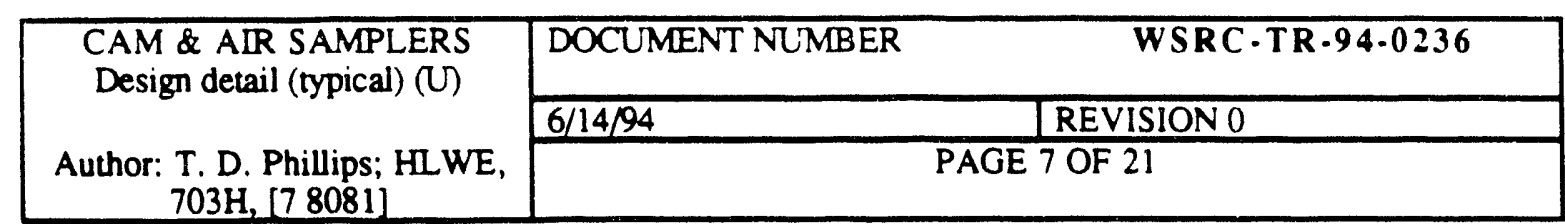

Stack velocity

(Per DOE/EH--0173T, Section 3.5.1)

A stack flow velocity indicator is required in order for the operator to determine that sample rates are properly set for isokinetic sampling. A velocity probe should be installed on the stack to provide manual readout of average stack velocity. and the velocity profile using EPA method 2 . Following that determination install a permanent local readout device such as an annubar or pitot tube to permit weekly verification as to the percent of stack flow change. The flow velocity measurement devices must be verifiable to \pm 10 $\%$ accuracy NIST.

One velocity test por in the stack designed to temporarily install a NIST traceable device with which to calibrate/verify accuracy of the permanent velocity probe.

Sample-transport lines (Per DOE/EH--0173T, Section 3.5.4)

The sample line connecting the nozzle to the sampler/monitor box is to be one inch stainlesssteel tubing. The run should be as short as possible. Changes in direction should be minimized and be made with radii of curvatures greater than 5 inches.

The shutoff ball valve installed at the sample nozzle is used to facilitate leak testing of the system. The full port ball valve should use a welded connection to the sample nozzle and a swagelock connection to the one inch SS tubing. (Figure 3) In leakage at the tubing connection will be detected during leak testing.

The shutoff valve installed on the outlet side of the rotameter should be a $5 / 8$ ball valve with swagelock fittings.

\section{Heat trace and thermal insulation}

In order to prevent condensation on the inside walls of the sample tubing and the sample box, surfaces should be held at a temperature above the sample air temperature. Stack air temperature are about $100^{\circ} \mathrm{F}$.
Sample collection/monitor box (Per DOE/EH.0173T, Section 3.5.7)

Location should be chosen to:

Optimize sample line design for minimum bends, minimum length, downhill slope, minimum condensation.

Promote ease of inspection by the Radcon inspector or other approved operator

\section{Desion}

The new EG\&G EL-900-PFD sample box has been tested and evaluated by HLWE and SRTC.

The EL-900-PFD meets all of the following sample box development program goals. [est. cost $\$ 1000$ each in quantity]

1) Sample is collected on (standard) $76 \mathrm{~mm}$ dia. filter paper

2) Filter paper is supported on a horizontal sintered metal filter paper holder [stage] designed to minimize Radon buildup and reduce difficulties of filter paper removal.

3) Filter paper stage in a drawer assembly to maximize ease of filter paper change, or probing.

4) Measurement chamber to be free of zero flow voids. (i.e.) all particles must be trapped on the filter paper.

5) GM detector if used is fixed at $1 / 2$ " above the filter paper. If unit is a sampler only; a blank is installed in place of the GM detector.

6) GM detector LND 7185 (or equal) is a waterproof 2" dia pancake probe installed in a cylindrical mechanical housing and electronically equivalent to tube type LND 7311 [phone 5166786141 ]. The detector must be ordered separately for use with sample boxes which are to become CAMs.

7) Extended GM probe life due to fact that filter paper change out does not require probe movement

8) Vacuum on the stack side of the filter paper [measurement chamber] to be used in lieu of flow alarm.

9) 'Working vacuum' of the measurement chamber to be about 3.0" water column with no more than $0.03 \mathrm{cfm}$ inleakage. Vacuum measurement will be taken via the sample line vacuum tap.

10) One inch ID air sample inlet into box.

11) Five eighths inch vacuum connection outlet from box. 


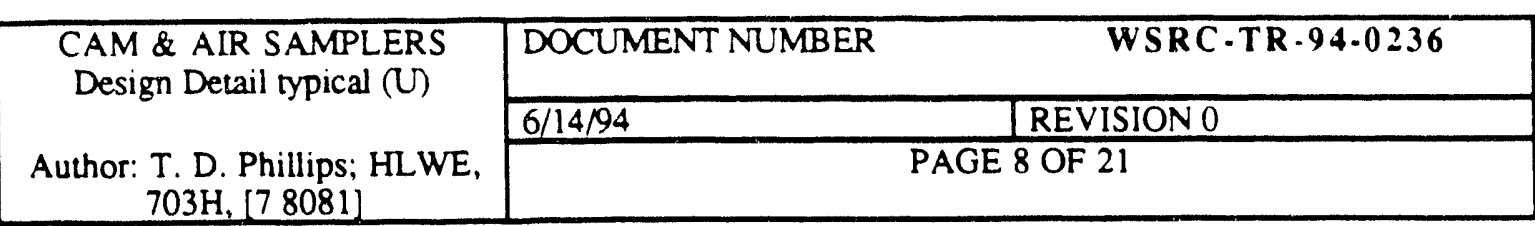

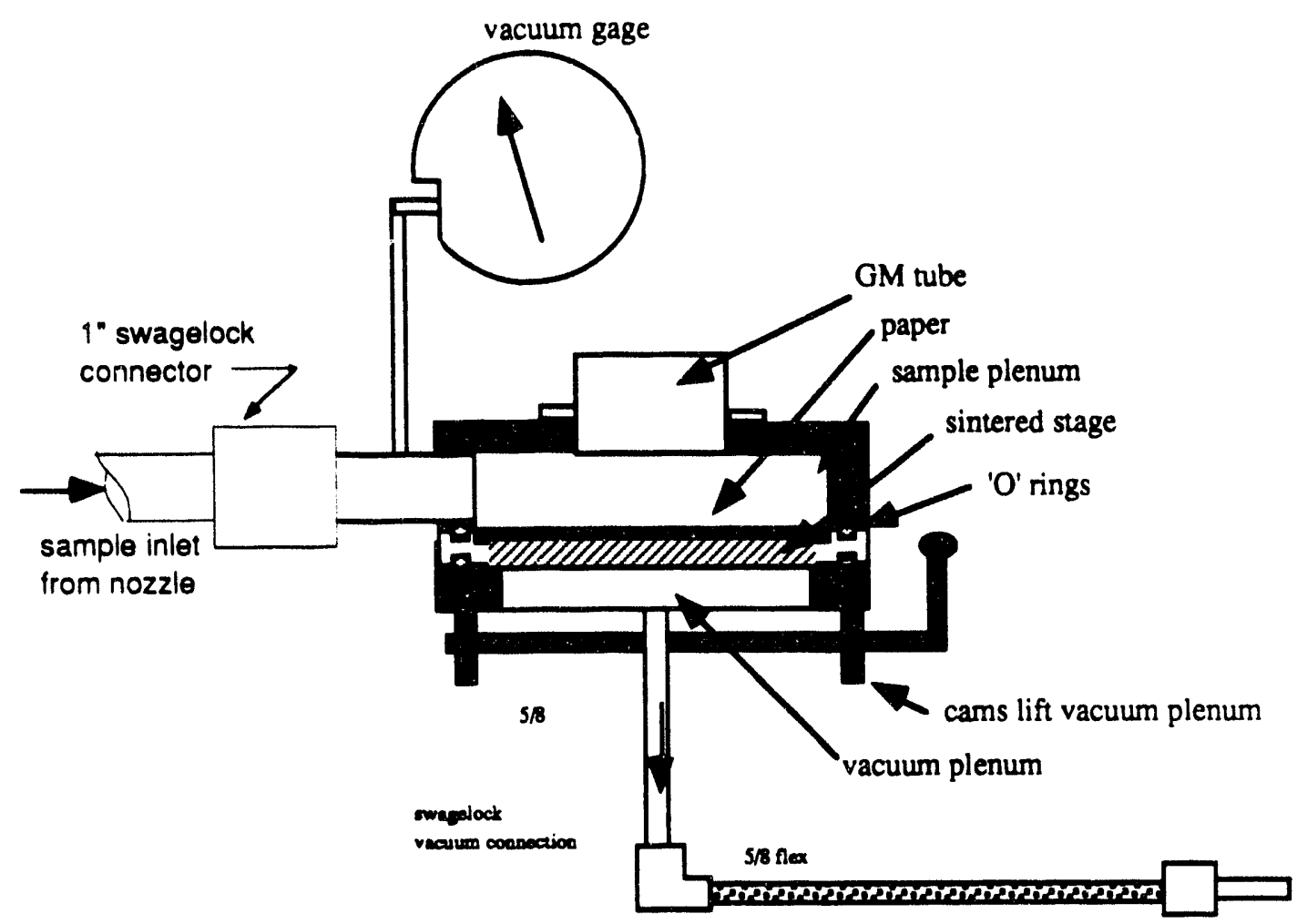

Eigure 4

\section{Illustrations of Prototype Sampler box [EG\&G]}

- CCW operation of the handle shown on the right hand in Figure 4 lowers the filter paper's sintered metal stage and the vacuum plenum by $1 / 4$ inch. When lowered, the vacuum seal is broken and the brass drawer holding the sintered metal stage and filter paper may be opened to provide access to the paper. 
CAM \& AIR SAMPLERS

Design Detail typical (U)

Author: T. D. Phillips; HLWE,

PAGE 9 OF 21



drawer dosed for sampling
PROTOMMEE SAMPLERPLANVEW

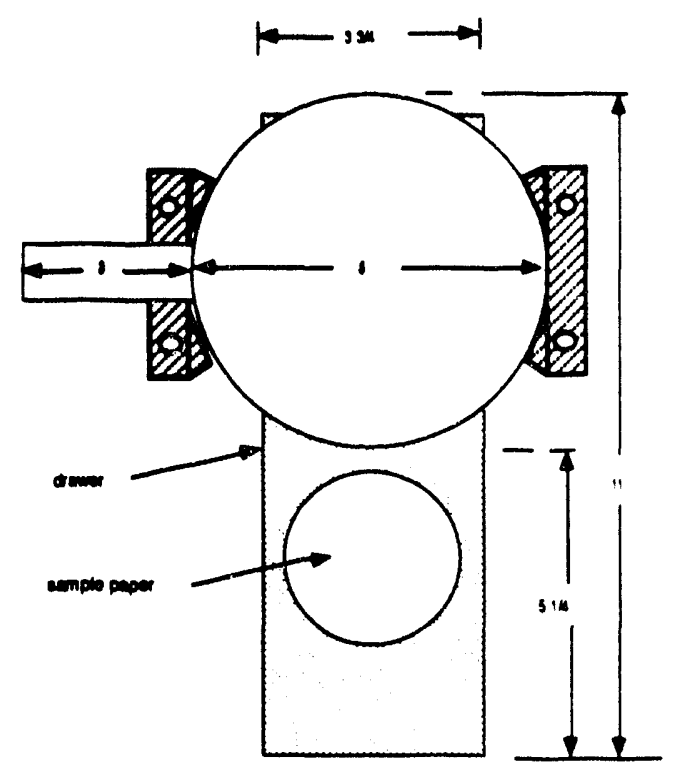

oremer open for replacement of filter paper



ELEVATION

Figure 5

The EL900 sampler can be oriented with the sample inlet to the right or left hand with the sample paper drawer opening towards the Radcon inspector. If rear entry sample inlet is chosen the sample paper drawer can be installed to open to the right or the left hand of the inspector. 


\begin{tabular}{|c|c|c|}
\hline \multirow{3}{*}{. $\cdot$} & \multirow{3}{*}{$\begin{array}{l}\text { CAM \& AIR SAMPLERS } \\
\text { Design Detail typical (U) } \\
\text { Author: T. D. Phillips; HLWE, } \\
\text { 703H. [7 8081] }\end{array}$} & DOCUMENT NUMBER \\
\hline & & REVISION 0 \\
\hline & & PAGE 10 OF 21 \\
\hline
\end{tabular}

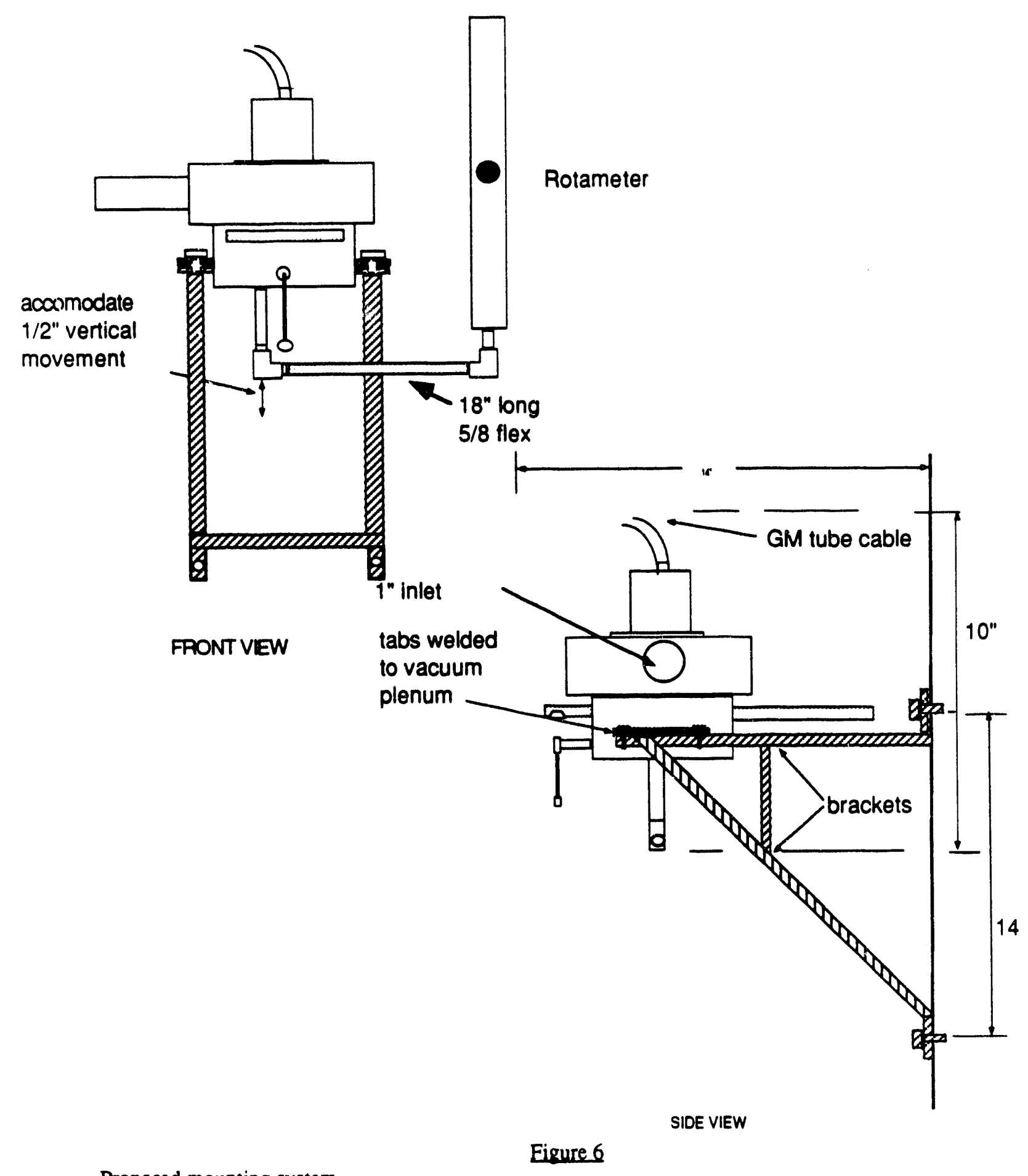

Proposed mounting system

- Support tabs welded to the $41 / 2$ " diameter inlet plenum shown cross hatched in Figures $5 \& 6$

- The $90^{\circ}$ connection at the bottom of the suction connection can be oriented in any direction. 


\begin{tabular}{|c|l|l|}
\hline CAM \& AIR SAMPLERS & DOCUMENT NUMBER & \multicolumn{2}{|c|}{ WSRC·TR-94-0236 } \\
Design Detail typical (U) & & REVISION 0 \\
\cline { 2 - 3 } & $6 / 14 / 94$ & PAGE 11 OF 21 \\
\cline { 2 - 3 } Author: T. D. Phillips; HLWE, & & \\
$703 \mathrm{H},[78081]$ & &
\end{tabular}

\section{Test system vacuum}

The optimum Sample System design should maximize particulate transport efficiency. For the $3 \mathrm{cfm}$ Waste Management sample rate we have assumed the use of one inch stainless steel tubing ( 0.83 " ID). Particle deposition and transport efficiency tests using the material illustrated by figure 7 are scheduled at the Texas A\&M aerosol testing laboratory during the third quarter 1994. Results of WSRC testing on the illustrated sample system follow. The sample line tested was a 10 foot long 1" stainless steel tube containing two 5" radius sweeps. The isokinetic nozzle was 0.5 " ID with a 2.5 " radius sweep per figures 2 \& 3 .

Conclusions:

- The proposed system will result in a sample vacuum near atmospheric pressure [0 to 0.5 " wc] at a flow of $3 \mathrm{cfm}$.

- Pressure drop across the filter paper is 16 " wc at $3 \mathrm{cfm}$ (see also figure 11)

- Pressure drop across the 100 micron porosity sintered metal stage is less than $0.1^{\text {" wc }}$ at $3 \mathrm{cfm}$

- Pressure drop across the rotameter is $7^{\text {" }}$ wc at $3 \mathrm{cfm}$

- Pressure drop due to the 10 feet of $1^{\prime \prime}$ tubing was $0.15^{\text {" wc at }} 3 \mathrm{cfm}$

- Pressure drop across the 0.5" ID nozzle was 0.3 " wc

(note that the figure 7 test was run with the nozzle intake at atmospheric pressure. The pressure in an actual $1700 \mathrm{fpm}$ exhaust duct is predicted to be about +0.5 " wc. Installation of the nozzle in ar: actual exhaust duct is expected to cause the vacuum at test point 3 to approximate 0 " wc)

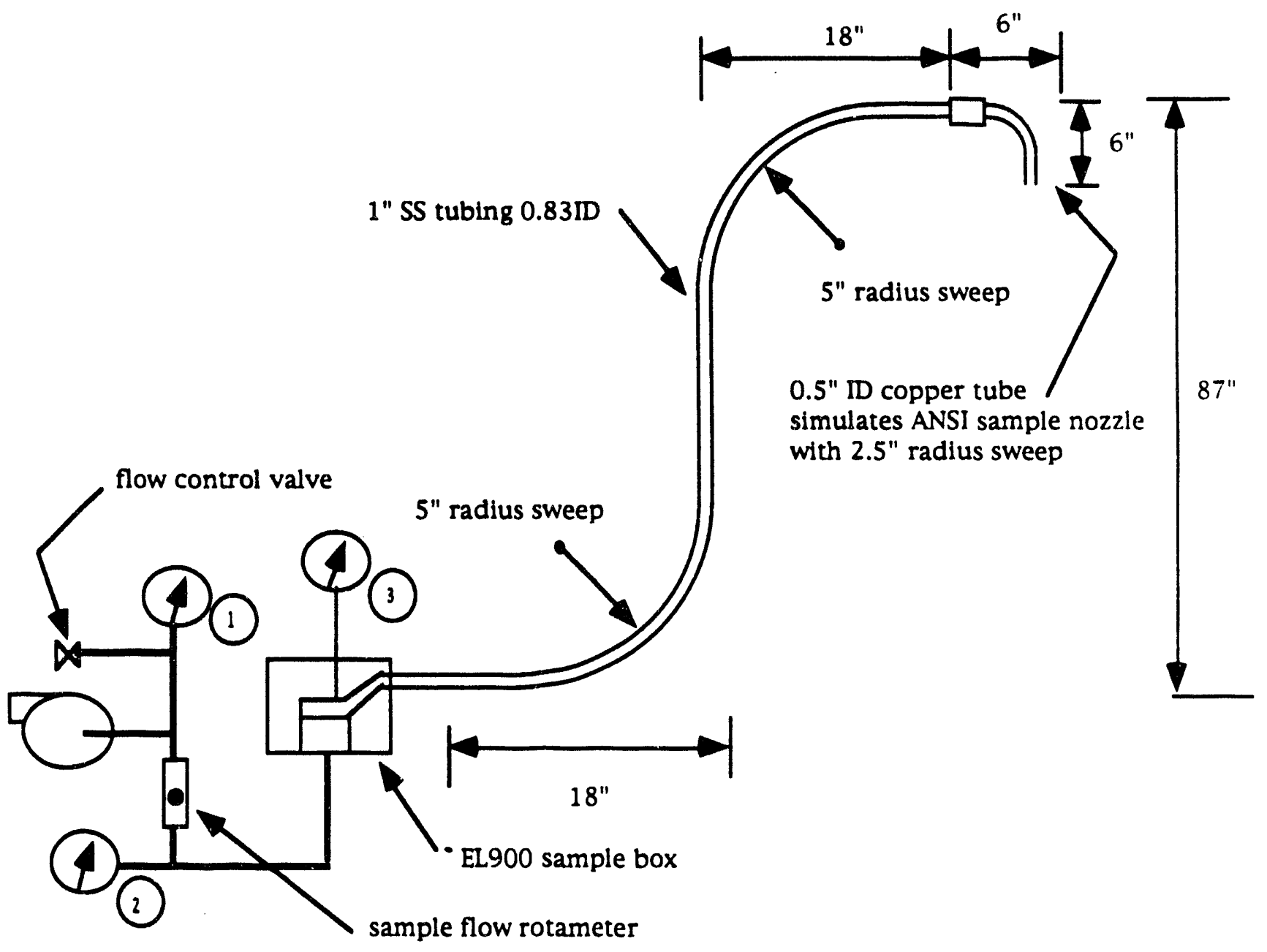

Figure 7 


\begin{tabular}{|c|c|}
\hline CAM \& AIR SAMPLERS & DOCUMENT NUMBER \\
\hline te & REVISION 0 \\
\hline $\begin{array}{c}\text { Author: T. D. Phillips; HLWE, } \\
703 \mathrm{H},[78081]\end{array}$ & PAGE 12 OF 21 \\
\hline
\end{tabular}

Test 1 conditions:

- sample nozzle in place

- 100 micron sintered metal stage in place

- filter paper in place

\begin{tabular}{|c|c|c|c|}
\hline $\begin{array}{c}\text { Vacuum 1 } \\
\text { inches water }\end{array}$ & $\begin{array}{c}\text { Vacuum 2 } \\
\text { inches water }\end{array}$ & $\begin{array}{c}\text { Vacuum 3 } \\
\text { inches water }\end{array}$ & sample flow cfm \\
\hline 15 & 11 & 0.25 & 2 \\
\hline 23 & 16.5 & 0.45 & 3 \\
\hline 35 & 23.5 & 0.75 & 4 \\
\hline 41 & 26.5 & 0.85 & 4.4 \\
\hline
\end{tabular}

Tes. 2 conditions:

- No sample nozzle (open 1" tubing)

- 100 micron sintered metal stage in place

- filter paper in place

\begin{tabular}{|c|c|c|c|}
\hline $\begin{array}{c}\text { Vacuum 1 } \\
\text { inches water }\end{array}$ & $\begin{array}{c}\text { Vacuum 2 } \\
\text { inches water }\end{array}$ & $\begin{array}{c}\text { Vacuum 3 } \\
\text { inches water }\end{array}$ & sample flow cfm \\
\hline 23 & 16 & 0.15 & 3 \\
\hline 35 & 23 & 0.25 & 4 \\
\hline
\end{tabular}

Test 3 conditions:

- sample nozzle in place

- 100 micron sintered metal stage in place

- No filter paper

\begin{tabular}{|c|c|c|c|}
\hline $\begin{array}{c}\text { Vacuum 1 } \\
\text { inches water }\end{array}$ & $\begin{array}{c}\text { Vacuum 2 } \\
\text { inches water }\end{array}$ & $\begin{array}{c}\text { Vacuum 3 } \\
\text { inches water }\end{array}$ & sample flow cfm \\
\hline 15 & 6.5 & 0.47 & 3 \\
\hline
\end{tabular}

Test 4 conditions:

- sample nozzle in place

- No 100 micron sintered metal stage

- No filter paper

\begin{tabular}{|c|c|c|c|}
\hline $\begin{array}{c}\text { Vacuum 1 } \\
\text { inches water }\end{array}$ & $\begin{array}{c}\text { Vacuum 2 } \\
\text { inches water }\end{array}$ & $\begin{array}{c}\text { Vacuum 3 } \\
\text { inches water }\end{array}$ & sample flow cfm \\
\hline 15 & 6 & 0.48 & 3 \\
\hline
\end{tabular}

\section{In-leakage}

Potential in-leakage will take place on the suction side of the monitor from the filter paper to the inlet (bottom) of the rotameter. During normal operation any other breaches in the sample line will be insignificant.

In-leakage into the sample system upstream of the filter paper should be insignificant because the vacuum upstream of the filter paper will be close to atmospheric pressure per the figure 7 test data.

In order 10 assure that in-leakage does not exceed $1 \%$ of the sample flow $(0.03 \mathrm{cfm})$ the system can be tested via a static leak test. A static leak test is performed by creating a static vacuum within the sample system and measuring the time required for the vacuum to bleed down. The test vacuum should approximately equal the normal working vacuum at test point 2 (figure 7). 


\begin{tabular}{|c|l|l|}
\hline CAM \& AIR SAMPLERS & DOCUMENT NUMBER & \multicolumn{2}{|c|}{ WSRC·TR.94.0236 } \\
\cline { 2 - 3 } Design Detail typical (U) & & REVISION 0 \\
\cline { 2 - 3 } Author: T. D. Phillips; HLWE, & & PAGE 13 OF 21 \\
\cline { 2 - 3 } & & \\
\hline
\end{tabular}

\section{Static Leak Test}

Inlet and outlet valves are required to permit static leak testing as a measure of sample box in-leakage.

The air in-leakage into an air sampling system can be quantified by closing the system, establishing a known vacuum, and timing the vacuum decay. The internal volume of a typical air sampling system will be 0.3 cubic foot or less. Connecting a large volume to the system under test extends the decay time (for a given rate of in-leakage). A portable test rig to include a 1 cubic foot volume, sample pump, controlled leak, vacuum gage, and necessary valving may be assembled for this purpose.

Decay time due to a known leak can be determined by establishing a measured $.03 \mathrm{cfm}$ leak into the test rig via a 'leak' rotameter on the test rig and timing the decay from between two vacuums such as $16^{\text {" }}$ to $10^{\text {"* }}$. The test rig is than connected to the system to be tested, the 'controlled leak' on the test rig is closed, and a 16 inch vacuum is established. If the resulting vacuum decay time from 16 to $10^{\prime \prime}$ is greater than the time established using the measured $.03 \mathrm{cfm}$ leak; the system has a leak rate of less than $.03 \mathrm{cfm}$ and is OK. *Vacuum to be measured using the vacuum gage installed on a portable 'leak test' rig

If vacuum decay time of the sample system without connection to the test rig is longer than the test rig's $.03 \mathrm{cfm}$ decay time than the test rig is not needed.

- Close the vacuum supply 'leak test valve'

- Close the sample inlet 'leak test valve'

[The mica window GM tube radiation detector can withstand a 80" wc vacuum.]

- Adjust the Sample control and Vacuum leak test valves in order to establish 16" wc on the vacuum gage.

- Close the Vacuum Leak Test valve, stop the vacuum pump, and time how long it takes for the vacuum to drop from 16" wc to 10" wc.

Leak data will necessarily include the inlet and outlet valve leak-thru rate.

The leak size which generated the following plot was determined to be less than $0.0003 \mathrm{cfm}$ at a working vacuum of 6" wc. 
Author: T. D. Phillips; HLWE,

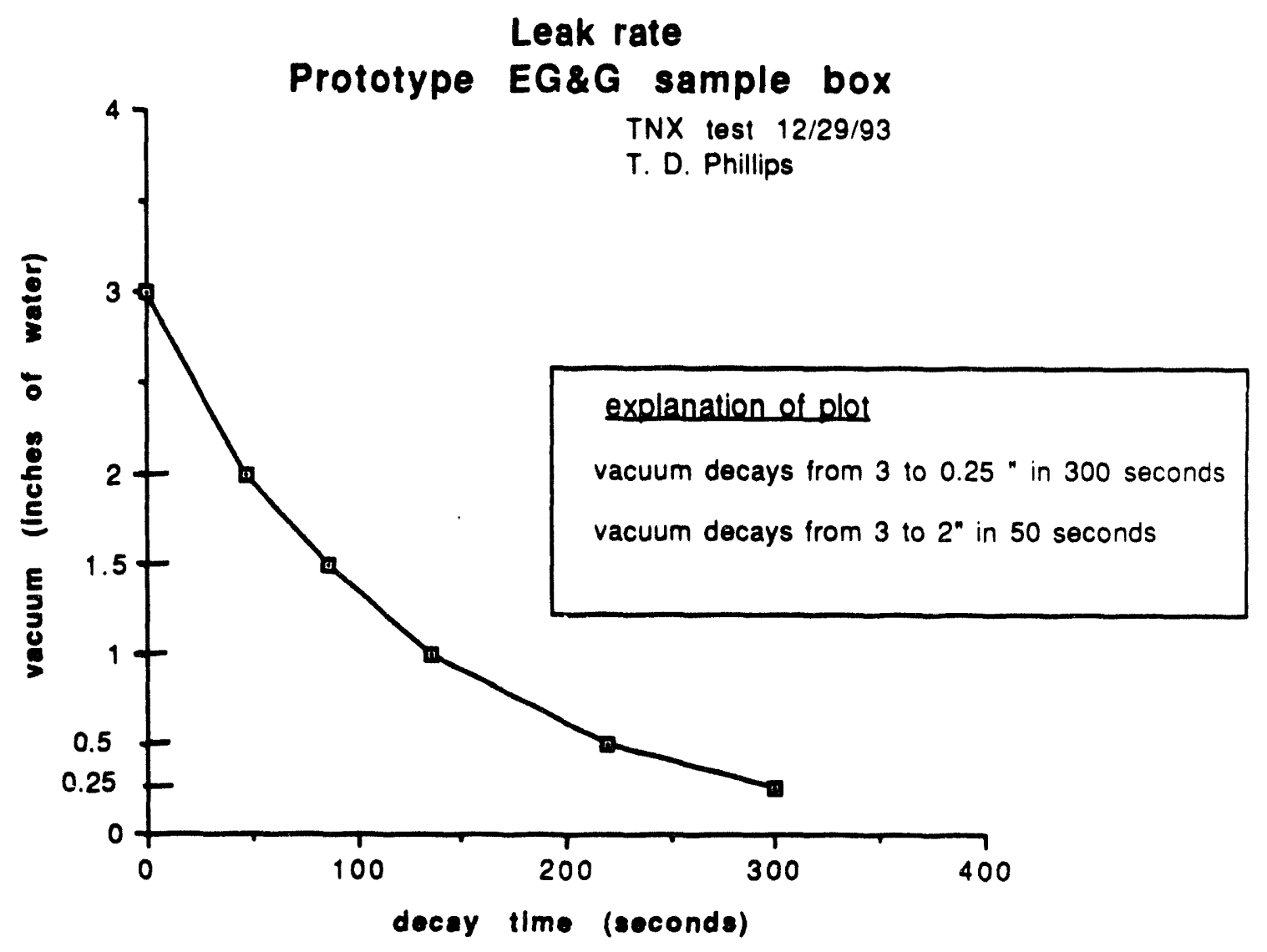

Eigure 8 


\begin{tabular}{|c|c|}
\hline CAM \& AIR SAMPLERS & DOCUMENT NUMBER \\
\hline & REVISION 0 \\
\hline $\begin{array}{c}\text { Author: T. D. Phillips; HLWE, } \\
703 \mathrm{H},[78081]\end{array}$ & PAGE 15 OF 21 \\
\hline
\end{tabular}

\section{Sample flow alarm}

Existing systems on tank purge and annulus CAMs initiate an annunciator point in the control room via sample pump differential pressure switch or an alarming rotameter. Neither of these existing system provide adequate indication in response to the various flow problems illustrated in the following chart. Flow alarm on the new CAMs should be initiated by an appropriately size hi/lo setpoint vacuum gage such as a Dwyer Photohelic.

Non-CAM air samplers are not equipped with either flow or radiation alarms, however new non-CAM samplers are to be equipped with a permanently installed vacuum gage such as a Dwyer Magnehelic to enable evaluation of system performance. Future conversion of air samplers into CAMs will require replacement of the Magnehelic to Photohelic gages in order to provide flow alarms.

Nominal sample rate for the tank farm samplers is $3 \mathrm{cfm}$. In-leakage is driven by the magnitude of the vacuums vac 2 and vac 3 [Figure 9]. Experimental data at $3 \mathrm{cfm}$ reveals that vac 2 will equal 16 inches plus the value of vac 3 . Vac 3 will be dependent upon sample system tubing length, number of bends, and nozzle size. Any abnormal condition such as in-leakage will cause the vacuum to shift from the normal working vacuum. Sampling system in-leakage of less than $1 \%$ of normal flow [ $3 \mathrm{cfm} \times 1 \%=.03 \mathrm{cfm}$ ] is acceptable for High Level Waste air samplers. Testing illustrated by figure 7 suggests that the vacuum at test point 3 will be close to atmospheric. Installation of the alarm gage at test point 2 will provide the following indications.

\begin{tabular}{|l|c|}
\hline Cause & meter indication \\
\hline Plugged filter paper & high vacuum \\
\hline Mis-positioned filter paper & low vacuum \\
\hline Damaged filter paper & low vacuum \\
\hline Sample pump problem & low vacuum \\
\hline In-leakgge equal to $10 \%$ of nomal flow & low vacuum \\
\hline Plugged sample line & high vacuum \\
\hline
\end{tabular}

An appropriately size vacuum gage [such as a 30" Dwyer Capsulhelic] should permit the inspector to verify that vacuum is within \pm 1 " wc of normal when the rotameter indicates the isokinetic sample flow. System design should attempt to produce isokinetic conditions at a sample flow of $3 \mathrm{cfm}$. Use of a Dwyer Photocapsulhelic gage will permit control room flow alarms to be initiated by either High vacuum or Low vacuum.

- Acceptable in-leakage for continuously operating air samplers is addressed by ANSI N42.17B Section 9.2 as less than $10 \%$ of nominal flow rate. [ $3 \mathrm{cfm} \times .1=0.3 \mathrm{cfm}$ ]. Acceptable inleakage is addressed by 10 CFR 60 method 5 as the lessor of $4 \%$ or $0.02 \mathrm{cfm}$. Consensus opinion at SRS favors a goal value of $1 \%[3 \mathrm{cfm} \times 0.01=0.03 \mathrm{cfm}]$

\section{Purge and/or annulus blower interlock}

Automatic shutdown of stack ventilation due to high radiation or sampler malfunction is not required as part of the standard High Level Waste air sampler or monitored sampler [CAMs] design; however Waste Removal Process Hazard Reviews (PHR) currently include action items and recommendations to interlock H\&V off due to high-high CAM activity. Waste removal projects such as S-2081, S-2860, etc. plan to add interlocks to exhaust systems where such interlocks are deemed appropriate. 


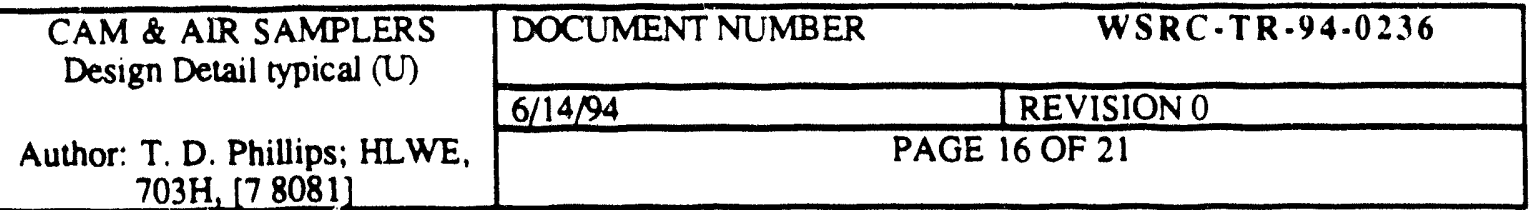

\section{Sample Elow measurement}

Sample box vacuum will be used in conjunction with the rotameter to indicate flow problems. In order to accomplish this it is important that the operator be able to read the sample flow to within $0.1 \mathrm{cfm}$. Use of a large 10" long rotameter such as Dwyer series RMC will permit sample flow rate readout to within $0.1 \mathrm{scfm}$ at $3 \mathrm{cfm}$. The rotameter will be used to indicate sample flow rate in $\mathrm{cfm}$. The $3 \mathrm{cfm}$ flow rate will be adjusted via the manual valve installed in parallel with the sample pump. At $3 \mathrm{cfm}$ the vacuum gage should read to within \pm 0.5 " wc of the previously established normal 'working vacuum'.

\section{Verification of Rotameter accuuracy}

Provide a means of inserting a calibrated rotameter or other flow measurement device in order to annually verify accuracy of the permanently installed rotameter. The layout (Figure 1) illustrates the use of a three valve assembly downstream of the rotameter. During normal operation valve $b$ is open and valves a \&c would be closed. For testing; place the test instrument between valves a \& c, close value $b$ and open $a \& c$.

\section{Air Movine System (Per DOE/EH--0173T, Section 3.5.5)}

System will be operated using a single pump. Current pump of choice in High Level Waste is the Roots model 22-U-RAI operating at about $850 \mathrm{~mm}$. $\triangle \mathrm{P}$ across the filter paper is proportional to the flow rate, at 3 $\mathrm{cfm}$ standard glass type filter paper on a $100 \mu$ stage has a pressure drop of 16 " of water. Pumps are installed out of the weather at the bottom of a NEMA 12 enclosure.

Figure 9 illustrates normal flows and pressure drops for the system 


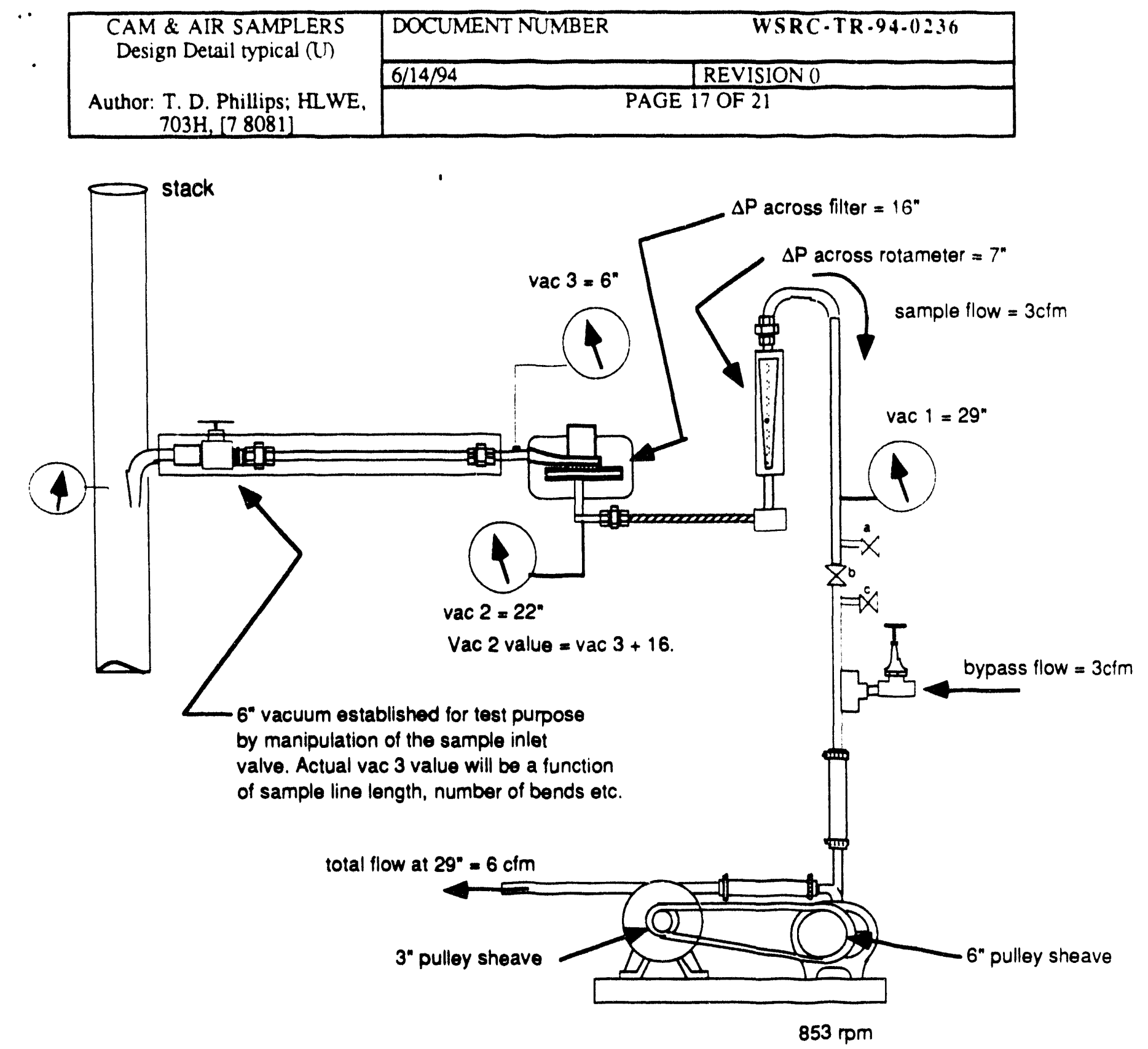

Figure 9 


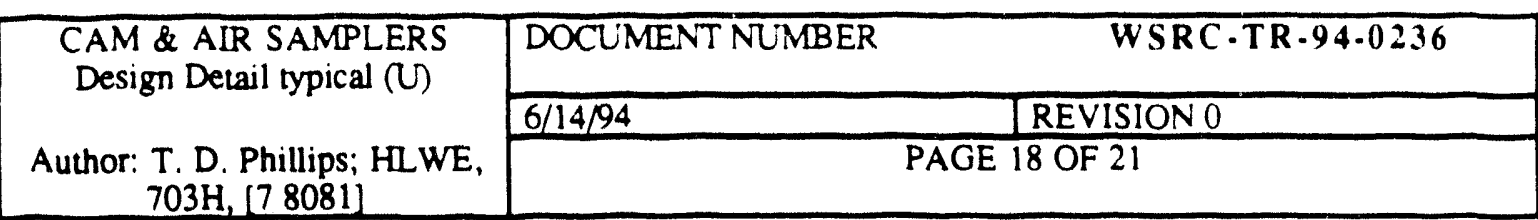

Nominal flow rate for stack air samplers is $3 \mathrm{cfm}$. The pressure drop across the filter is a function of the flow and the filter assembly. Figure 10 illustrates the change in $\triangle \mathrm{P}$ across standard filter on a $100 \mu$ metal stage due to a change in sample flow setting.

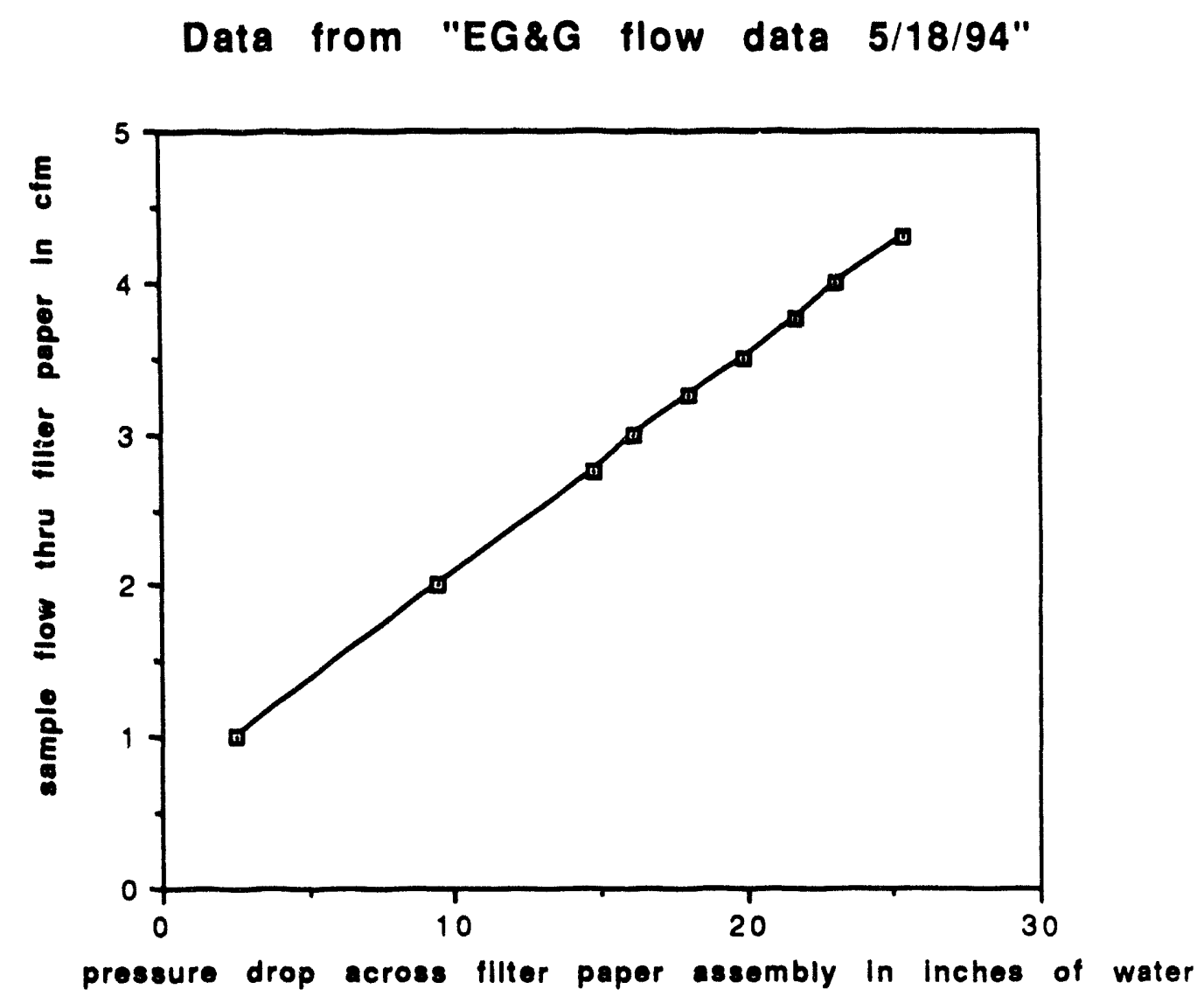

Figure 10 


\begin{tabular}{|c|l|l|}
\hline CAM \& AIR SAMPLERS & DOCUMENT NUMBER & \multicolumn{2}{|c|}{ WSRC-TR-94-0236 } \\
Design Detail typical (U) & & REVISION 0 \\
\cline { 2 - 3 } & $6 / 14 / 94$ & PAGE 19 OF 21 \\
\cline { 2 - 3 } Author: T. D. Phillips; HLWE, & & \\
$703 \mathrm{H},[78081]$ & &
\end{tabular}

Pump operating characteristics are dependent upon the pump rpm. Figure 11 illustrates the total air flow through the pump as a function of the pump vacuum [ $\mathrm{vac} 1$ on Figure 8] for a pump operating at $853 \mathrm{cfm}$. Motor amperage $=4.9$ amps over the total range of vacuum at $853 \mathrm{rpm}$. Increasing the pump speed to 1000 $\mathrm{rpm}$ by changing the pulley ratio to $3: 5$ will increase the available total air flow by about $2 \mathrm{cfm}$. Increasing pump speed requires additional motor horsepower, and may require increasing the size of the $1 / 3 \mathrm{hp}$ motor.

\section{Data from "roots data 5/18/94"}

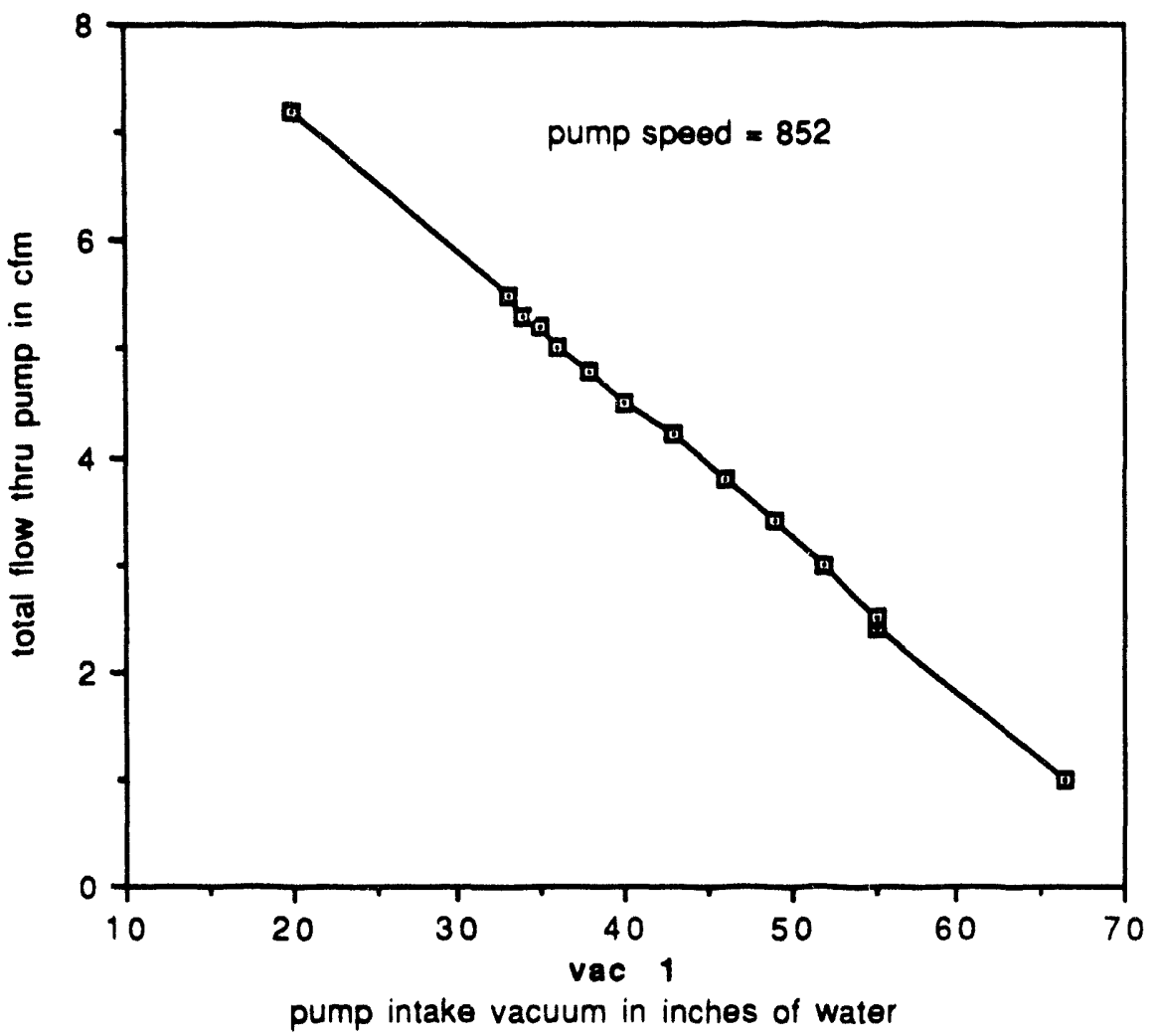

Figure 11 


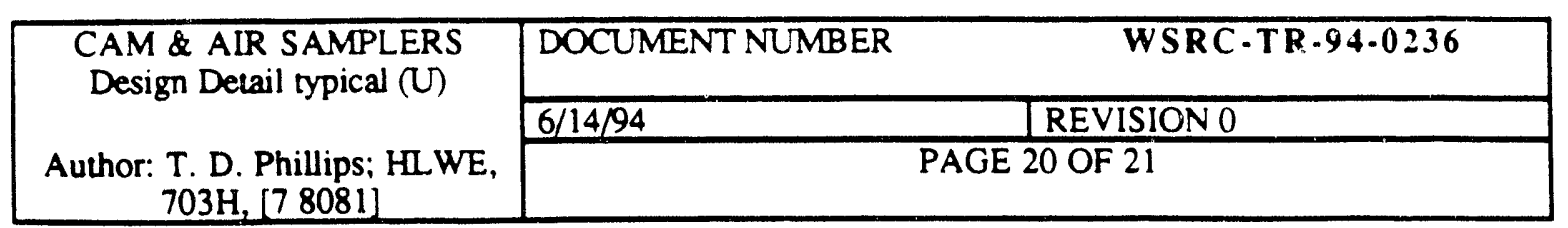

\section{Continuous Monitoring System Per DOE/EH--0173T Section 3.5.8 \&3.5.8.2}

The radiation detector designed for (optional) installation in the sample/monitor box is a waterproof version of the G-M probe in our existing CAMs. [LND Inc. type 8767 neon gas filled with mica window]

\section{Detector}

Technical - Neon gas fill to a pressure of $650 \mathrm{~mm}$ mercury (i.e.) the probe is under a vacuum.

Electrical - 800 to 900 volts dc is required at the probe. The probe does not require a field pre-amplifier.

Environmental - The mica window is sealed to the steel probe body with a glass seal. Waterproof G-M detectors should be purchased separately from the sample/monitor box. Mica window will fail due to applied vacuums approaching 15 "wc.

Response - Tests using a $1 \mu$ Curie Cesium 137 source indicate that the probe responds to both beta and gamma radiation. [ $12000 \mathrm{cpm}$ due to beta and $6000 \mathrm{cpm}$ due to gamma]

\section{Cabie}

RG.59U (low noise) coaxial cable is currently installed between the G-M tube detector and the control room for each sample/monitor box. The existing cable is adequate for use with the Upgrade CAM design.

The probe is connected to the Val-tech count rate meter [CRM] in the control room and has provin adequate in lengths of up to 1000 feet in length.

\section{Count Rate Meter}

The control room mounted Val-rech Mod IV CRMs are existing and are adequate for use with the Upgrade CAM design. The Mod IV is a linear output multiscale instrument

$0-1 \mathrm{~K}$

$0-3 \mathrm{~K}$

$0 \cdot 10 \mathrm{~K}$

$0-30 \mathrm{~K}$

$0-100 \mathrm{~K}$

Some CAMs are equipped with Val-tech Mod V CRMs which use a single 0 -100K logarithmic output analog display. 


\begin{tabular}{l|l|l|}
\hline CAM \& AIR SAMPLERS & DOCUMENT NUMBER & \multicolumn{2}{|c|}{ WSRC-TR-94-0236 } \\
Design Detail typical (U) & & \multicolumn{2}{|c|}{} \\
\cline { 2 - 3 } & $6 / 14 / 94$ & REVISION 0 \\
\cline { 2 - 3 } Author: T. D. Phillips; HLWE, & & PAGE 21 OF 21 \\
703H, [7 8081] & &
\end{tabular}

\section{Existing air Monitoring/Sampling Deficiencies}

Numerous deficiencies have been identified with both the unmonitored samplers and the CAMs. The following (8) deficiencies are listed in order of significance.

1) No sample collection nozzle in duct or stack results in low collection efficiency.

2) Improperly designed sample line [ small ID, long length, excessive bends, use of $90^{\circ}$ bends, use of knockout pot upstream of sample box] results in high line losses and particle buildup in sample system

3) Poorly designed sample box [not air tight, paper removal difficult, paper not held in position]. Poor reliability of sample collection on filter paper.

4) Not continuously monitored (unmonitored air samplers) could result in late detection of HEPA failure.

5) Water accumulation in sample box and/or rotameter restricts flow and destroys sample paper

6) Unsatisfactory flow alarm is unable to detect leaky box.

7 Incorrect sample point [ to close to flow disturbance] results in non-representative samples

8) Anisokinetic (low sample rate) results in 'lower than' representative count rate 

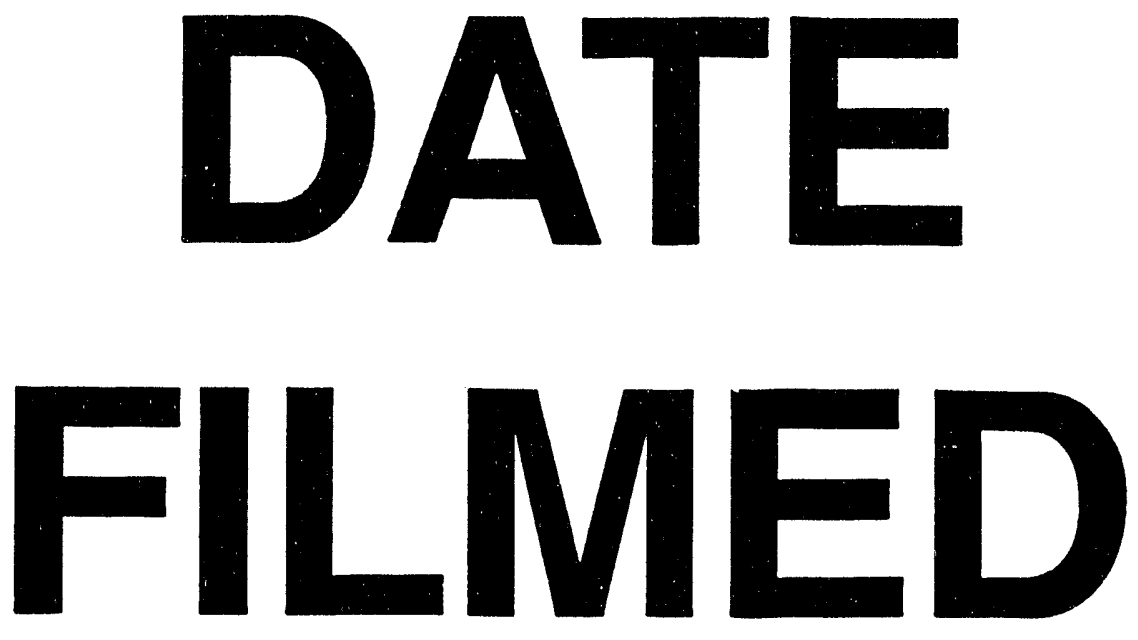

$10 / 18 / 94$
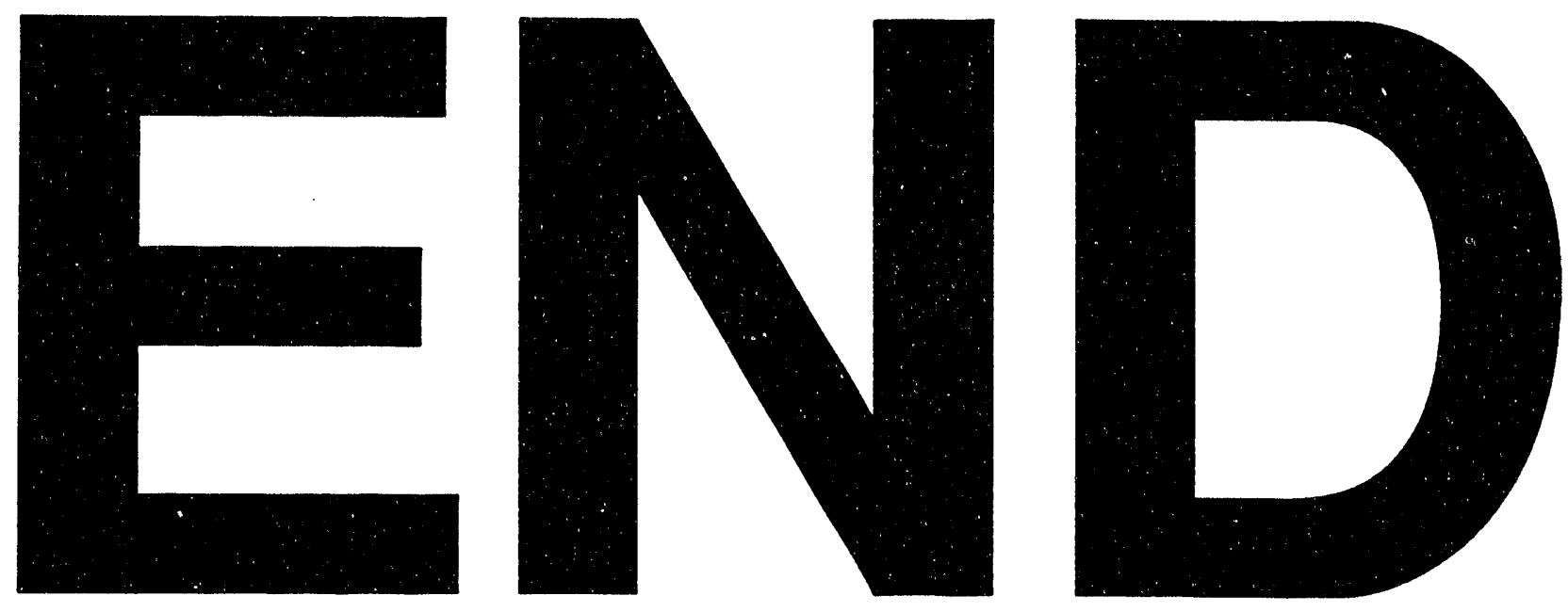
